\title{
ANALIZA IZVOZNE KONKURENTNOSTI HRVATSKOG IKT SEKTORA
}

\author{
THE ANALYSIS OF EXPORT COMPETITIVENESS \\ OF CROATIAN IKT SECTOR
}

SAŽETAK: Informacijske i komunikacijske tehnologije (IKT) imaju veliku ulogu na rast i razvoj zemalja putem izravnih i neizravnih utjecaja. Izravni utjecaj odnosi se na doprinos IKT-a kao jednog od sektora u gospodarstvu, koji sudjeluje u uvozu, izvozu i bruto domaćem proizvodu (BDP-u). Neizravni učinak očituje se kroz doprinos IKT-a digitalizaciji i povećanju ekonomičnosti u drugim sektorima, pri čemu ti sektori postaju konkurentniji. Cilj ovog rada je analizirati konkurentnost hrvatskog IKT sektora. Podaci pokazuju da u hrvatskom IKT sektoru dominiraju usluge te da se njihov izvoz od 2005. do 2019. godine povećao skoro tri puta. Također je zabilježen rastući udio IKT usluga u ukupnom izvozu usluga. Uvoz IKT usluga pokriven je u cijelom promatranom razdoblju izvozom; pokrivenost se povećavala te je u 2019. godini uvoz pokriven gotovo dva puta, međutim uvoz proizvoda nije pokriven. Nadalje, doprinos IKT-a BDP-u iznosi oko $4 \%$ i nije se značajnije mijenjao u razdoblju od 2008. do 2017. godine, što je u skladu s europskim trendovima. IKT sektor Hrvatske na međunarodnom tržištu nema komparativnu prednost, iako je ona kod IKT usluga viša nego kod proizvoda, doživjela je značajan pad u razdoblju od 2005. do 2019. godine, što ukazuje na pogoršanje konkurentske pozicije.

KLJUČNE RIJEČI: konkurentnost, IKT sektor Hrvatske, konkurentnost IKT-a, komparativna prednost

SUMMARY: Information and communication technologies (ICT) play a major role in the growth and development of countries through direct and indirect impacts. The direct impact refers to the contribution of ICT as one of the sectors of the economy that participates in imports, exports and gross domestic product (GDP). The indirect effect is manifested through the contribution of ICT to digitalization and increasing economy in other

\footnotetext{
*_Borna Vidović, mag. oec., Ministarstvo poljoprivrede, bvidovicb@gmail.com

***Doc. dr. sc. Lucija Rogić Dumančić, Sveučilište u Zagrebu, Ekonomski fakultet - Zagreb, lrogic@efzg.hr
} 
sectors, making these sectors more competitive. The aim of this paper is to analyze the competitiveness of the Croatian ICT sector. The data show that the Croatian ICT sector is dominated by services and that their exports increased almost threefold from 2005 to 2019. A growing share of ICT services in total exports of services was also recorded. Imports of ICT services were covered by exports throughout the observed period; coverage increased and in 2019 imports were covered almost twice, however, product imports are not covered. Furthermore, the contribution of ICT to GDP is around $4 \%$ and did not change significantly in the period from 2008 to 2017, which is in line with European trends. Croatia's ICT sector hasn't comparative advantage on the international market, although it is higher in ICT services than products, it experienced a significant decline in the period from 2005 to 2019, which indicates on declining competitive position.

KEY WORDS: competitiveness, ICT sector of Croatia, competitiveness of ICT, comparative advantage

\section{UVOD}

Razvoj poduzeća, ali i država u suvremenim uvjetima koje karakterizira globalizacija i internacionalizacija poslovanja ne može se zamisliti bez informacijske i komunikacijske tehnologije (IKT) (neki domaći autori koriste i kraticu ICT od engl. Information and communications technology). Naravno da su to shvatila sva poduzeća koja se žele uspješnije suočiti s konkurentskim pritiscima, a u prilog tome govori i činjenica da u Hrvatskoj $98 \%$ poduzeća koristi računala i ima pristup internetu (Državni zavod za statistiku, 2019). Europska unija također je prepoznala važnost IKT-a te je putem programa Digital Europe Programme 2021 - 2027 osigurala 9,2 milijardi eura za digitalizaciju društva i povećanje tehnološke autonomije (Europska komisija, 2020). Svjetski ekonomski forum (engl. World Economic Forum - WEF) objavio je rezultate nove studije gdje, između ostalih pokazatelja konkurentnosti predstavlja i usvajanje informacijske i komunikacijske tehnologije. Hrvatska je u 2019. godini zauzela 60. mjesto od 141 zemlje obuhvaćene studijom (Schwab, 2019).

Također, visoke stope rasta bruto dodane vrijednosti IKT sektora u Hrvatskoj, posebno u posljednjih nekoliko tromjesečja, upućuju na njegov pozitivan trend razvoja (Državni zavod za statistiku, 2020). Brojna istraživanja analiziraju doprinos informacijske i komunikacijske tehnologije rastu ekonomskih pokazatelja zemalja. Međutim, velik dio njih usmjerava se na specifičan doprinos digitalizacije i uvođenja IKT-a u poslovanje te tako mjere doprinos gospodarskom rastu, primjerice, kroz porast produktivnosti (Jorgenson i Stiroh, 2000; Delina, 2004; Cortez i Navarro, 2011 i Dahl et al., 2011) ili kroz doprinos digitalizacije smanjenju nejednakosti raspodjele dohotka (Cioaca et al., 2020). S druge strane neka recentna istraživanja u razvijenim zemljama zaključuju da polako dolazi do pada produktivnosti zbog, između ostalog, slabljenja doprinosa IKT-a (Crafts i Mils, 2020 i Mollins i St-Amant, 2019). Proučavajući sektorski doprinos pojedinih djelatnosti rastu BDP-a neki autori usmjerili su se na specifičan doprinos informacijske i komunikacijske tehnologije (Ducker, 2010 i Duc i Linh, 2020).

Velika važnost IKT-a došla je do izražaja na nacionalnoj, ali i svjetskoj razini, nedavno za vrijeme vrhunca krize uzrokovane novim koronavirusom (COVID-19). Zbog uvo- 
đenja restrikcija kretanja i okupljanja ljudi u mnogim zemljama postala je upitna i gospodarska aktivnost, odnosno izvršavanje poslova na radnim mjestima. Kiraly et al. (2020) smatraju da su informacijske i komunikacijske tehnologije omogućile održavanje, barem jednim dijelom, gospodarske aktivnosti jer je omogućeno velikom broju ljudi da rade od kuće, a između ostalog njihov doprinos je i u održavanju društvene povezanosti u toj teškoj situaciji. Nadalje, iako je koronakriza uzdrmala svjetsko gospodarstvo, ipak, neki su autori istaknuli koristan učinak na digitalizaciju zemalja (Skulmowski i Rey, 2020; Shkalenko i Fadeeva, 2020 i Ojo, 2020). Naravno to sve ne bi bilo moguće bez podrške IKT sektora, čime se u prvi plan stavlja njegov daljnji razvoj u budućnosti.

Slijedom svega iznijetog očekuje se sve veća potreba za razvojem IKT-a u Hrvatskoj i svijetu, a time i porast udjela IKT-a u izvozu i bruto domaćem proizvodu (BDP), stoga u ovoj analizi ima smisla veću pažnju posvetiti upravo tom sektoru.

Nedavna, i još uvijek aktualna, kriza uzrokovana koronavirusom ponovno je pokrenula pitanje konkurentnosti hrvatske industrije. Informacijska i komunikacijska industrija često se spominje kao jedna od industrija s najvećim potencijalom rasta u Hrvatskoj te se smatra važnim temeljem razvoja ekonomije zemlje u budućnosti. Međutim, provedeno je vrlo malo istraživanja o konkretnom položaju IKT-a u strukturi industrije zemlje, kao i istraživanja o izvoznim performansama tog sektora. Glavni je cilj ovog rada analizirati konkurentnost hrvatskog IKT sektora na međunarodnom tržištu i odrediti značaj IKT-a u izvozu. Zatim napraviti sveobuhvatan pregled dosadašnjih istraživanja te ih sumirati. Također, kako bi se pokrio jaz u literaturi, cilj je rada dati odgovor na sljedeća istraživačka pitanja: (i) Kako se kretao doprinos IKT-a BDP-u Hrvatske u posljednjih 10 godina i što prevladava u strukturi samog sektora? (ii) Kakav je udio izvoza IKT-a proizvoda i usluga u ukupnom izvozu Hrvatske u odnosu na posttranzicijske zemlje Europske unije?, (iii) Kako se kretao izvoz IKT proizvoda i usluga Hrvatske u odnosu na Europsku uniju?, (iv) Kakva je pokrivenost hrvatskog IKT uvoza izvozom u posljednjih 15 godina?, (v) Postoji li izražena komparativna prednost hrvatskog IKT sektora?

Ovaj rad pridonosi postojećoj literaturi i boljem razumijevanju konkurentnosti sektora informacijske i komunikacijske tehnologije Hrvatske. Naime, određivanjem temeljne strukture sektora informacijske i komunikacijske tehnologije neophodnih za mjerenje specifičnih doprinosa robnom izvozu i izvozu usluga omogućuje utvrđivanje parcijalnog doprinosa sektora informacijske i komunikacijske tehnologije. Ovo istraživanje pridonosi u određivanju konkurentnosti Hrvatske jer definira razinu izražene komparativne prednosti Hrvatske u sektoru informacijske i komunikacijske tehnologije. Također, razvija se višedimenzionalni okvir za mjerenje konkurentnosti, što bi se moglo primijeniti i na druge sektore gospodarstva.

Rad je podijeljen u pet poglavlja. Nakon uvodnog dijela, u drugom je poglavlju prikazan pregled dosadašnjih istraživanja na temu konkurentnosti hrvatskog IKT sektora. Treće poglavlje daje teorijski pregled koncepta konkurentnosti. Četvrto poglavlje odnosi se na analizu podataka o IKT sektoru Hrvatske te usporedbu s odabranim razvijenim i posttranzicijskim zemljama Europe. U zaključku su iznesene spoznaje na temelju dobivenih rezultata istraživanja. 


\section{PREGLED LITERATURE}

\subsection{Definiranje pojma informacijske i komunikacijske tehnologije}

Etimološko značenje informacijske tehnologije - IT i informacijske i komunikacijske tehnologije - IKT često predstavljaju problem obuhvata i razumijevanja kod krajnjih korisnika, ali i ne toliko rijetko u sredstvima izvještavanja javnosti. Stoga, polazeći od rada Ebijuwa (2005) i ToAnyakoha (2005), ali i nekih drugih radova, primjerice Sivakumarena et al. (2011) i Hentena i Tadayonia (2015) može se napraviti distinkcija pojmova i obuhvata. Prije svega prisutan je stav da je IT stariji pojam koji predstavlja alate i sredstva za prikupljanje i obradu podataka te pružanje informacija. S druge strane IKT predstavlja integraciju IT-a s audiovizualnim i prijenosnim (komunikacijskim) tehnologijama. Stoga se može reći da je IT podskup IKT-a, s time da IKT dodatno omogućava prijenos i pristup podacima širokom spektru korisnika. Problematikom definiranja i obuhvata informacijske i komunikacijske tehnologije bavili su se i u Ujedinjenim narodima u Department of Economic and Social Affairs (2008) koji navode da je određivanje ovog sektora važno za usporedivost statističkog mjerenja, posebice na međunarodnom nivou. IKT sektor definiraju kao proizvodnju roba i usluga koje su namijenjene obradi podataka ili je omogućuju te podržavaju komunikaciju elektroničkim putem, uključujući prijenos i prikaz podataka. Sličnu definiciju daje i OECD (2009), ali je proširuje vrednovanjem proizvoda IKT industrije, gdje vrijednost proizvoda ne leži u njegovim opipljivim karakteristikama već u njegovim osobinama: informativni, obrazovni, kulturni i zabavni sadržaj. IKT sektor može se podijeliti na proizvode i usluge. Prema OECD-u (2011) u IKT sektor spadaju sljedeće skupine: (1) među proizvode: računala i periferna oprema, komunikacijska oprema, potrošačka elektronika, razne IKT komponente i roba, (2) među usluge: servis IKT uređaja i opreme, razvoj softvera za poslovanje i licenciranje, konzultantske usluge vezane za IKT, telekomunikacijske usluge, leasing i najam IKT opreme te ostale IKT usluge.

Informacijske i komunikacijske tehnologije omogućuju digitalizaciju poslovnih procesa, što zajedno s radom, kapitalom i ljudskim resursima poboljšava performanse na mikrorazini tj. u poduzećima, a to posljedično utječe i na konkurentnost države (OECD, 2019).

Uvažavajući definicije relevantnih ustanova i institucija te puno češćoj upotrebi pojma informacijske i komunikacijske tehnologije u znanstvenoj literaturi od pojma informacijske tehnologije, u ovom radu koristit ce se pojam informacijska i komunikacijska tehnologija. Dodatni motiv zbog kojeg je odlučeno analizirati IKT jest i dostupnost podataka koji se uglavnom svode na podjelu u IKT sektoru.

\subsection{Koncept konkurentnosti}

Konkurentnost se smatra višedimenzionalnim ekonomskim pojmom koji unatoč svoje široke upotrebe nema konsenzusa oko njegove definicije i mjerenja. Kao takav može se promatrati na mikrorazini koja se odnosi na poduzeća, mezorazini koja se odnosi na industrije, odnosno makrorazini koja se odnosi na zemlje. Uloga države u tom smislu je osigurati stabilno ekonomsko okruženje, javne usluge i infrastrukturu (Anca, 2012). S obzirom na to da se konkurentnost smatra ključnim aspektom moderne ekonomske politike i uspjehom zemlje, Europska unija u svojim strategijama često u prvi plan stavlja poboljšanje konku- 
rentnosti. Prema Europskoj uniji (2002) konkurentnost je stupanj do kojeg država može iskorištavati slobodno tržište i pošteno tržišno natjecanje kako bi ponudila robu i usluge na međunarodnim tržištima, istovremeno održavajući i povećavajući dohodak svojih stanovnika. Utvrđen je niz pokazatelja u analizi konkurentnosti zemalja iz sektorske perspektive. Dio njih; primjerice produktivnost rada i jedinični troškovi rada mogu se smatrati glavnim dijelom konkurentnosti, dok drugi pokazuju učinak industrija u tržišnim aktivnostima i međunarodnoj trgovini (Psychoyios i Dotsis, 2018).

Konkurentnost se kao pojmovni okvir ekonomskih analiza javlja u osamdesetim godinama 20. stoljeća. Upravo konkurentnost predstavlja moderan termin koji s povećanjem nadmetanja u suvremenoj, sve više otvorenoj i integriranoj, svjetskoj ekonomiji postaje predmet mnogih istraživanja (Tijanić, 2002). To razdoblje u svijetu karakterizira izrazit razvojno-konceptualni zaokret. Od komparativnih prednosti prema konkurentskim prednostima nacije i svake pojedine tvrtke. Prirodni resursi i potencijal lokacije izgubili su vodeću ulogu, a sve važniji postaje način kako u ukupnom procesu stvaranja sve sofisticiranijih proizvoda i usluga biti što uspješniji od drugih (Vedriš, 2005).

OECD-ova definicija konkurentnosti (OECD, 2001; prema Rašić-Bakarić, Vizek, 2010, str. 242) koju na razini države definira kao stupanj do kojeg država može proizvoditi robu i usluge koje bi trebale proći test međunarodne konkurencije i istovremeno održavati i razvijati svoje prihode na nacionalnoj razini u uvjetima liberalizacije tržišta.

Konkurentnost se može promatrati na mikro i makrorazini. Na mikrorazini, razumijevanje koncepta konkurentnosti odnosi se na sposobnost natjecanja poduzeća kako bi rasla i bila produktivna. Poduzeće će biti konkurentno ako je razina njegovih troškova jednaka ili manja od razine konkurenata uz pretpostavku ostvarivanja podjednake razine prihoda, odnosno ako poduzeće održava troškove na razini konkurenta, ali uz realizaciju puno većih prihoda. Dakle, na ovoj razini konkurentnost se sastoji u sposobnostima poduzeća da na profitabilan način proizvedu robu koja će odgovarati zahtjevima tržišta (Škuflić et al., 2011).

Kada se konkurentnost razmatra na makrorazini, koncept konkurentnosti je neodređenije definiran i mnogo kontroverzniji. Unatoč činjenici da se u globalu smanjuje razlika u konkurentnost nacija i regija, konkurentnost je središnja svrha svake ekonomske politike, a nedostatak jednoglasno prihvaćene definicije predstavlja izvor stalne polemike Anca (2012). Primjerice Krugman (1994) opisuje nacionalnu konkurentnost kao „opasnu opsesiju koja sve više raste." Smatra da je koncept nacionalne konkurentnosti zbunjujući te da se ne može povezivati konkurentnost poduzeća i države, prema tome smatra da koncept konkurentnosti nije primjenjiv na razini zemlje. Međutim, kako postoje razlike u uspješnosti pojedinih zemalja Martin (2004) shvaća da poboljšanje učinka jedne nacije mora biti na štetu druge, stoga smatra da se konkurentnost na nacionalnoj razini temelji na superiornijoj produktivnosti i sposobnosti gospodarstva za preusmjeravanje proizvodnje u industrije visoke dodane vrijednosti.

Strategija, odnosno na koji način će se ostvariti željena konkurentnost ovisi o samoj strukturi sektora i dinamikama u njemu. U svakom sektoru konkurentnost je utjelovljena u pet čimbenika: odnos konkurentnosti među poduzećima koja posluju u određenoj industriji, prijetnja potencijalnih ulazaka ako profitabilnost dovoljno poraste, prelazak kupaca na supstitute, pregovaračka moć kupaca i pregovaračka moć dobavljača (Porter, 1998).

U zavisnosti od sektora do sektora razlikuje se i ovih pet čimbenika, u nekim su ti čimbenici izraženiji, primjerice IKT, kozmetika, lijekovi i slični sektori gdje se ostvaruje 
veliki povrat na uloženi kapital. Također, te industrije su važnije za veći životni standard i država može na različite načine poticati ulazak i jačanje konkurentnosti. Međutim, životni će standard nacije u konačnici ovisiti o sposobnosti poduzeća da prodru u strukturno atraktivnije industrije. Neke zemlje u razvoju često su ulazile u strukturno neprivlačne industrije i tako dodatno pogoršale svoju međunarodnu konkurentnost (Porter, 1998).

\subsection{Pregled istraživanja o konkurentnosti IKT sektora}

Škuflić i Vlahinić-Dizdarević (2003) razmatraju koncept Nove ekonomije i značaj informacijske i komunikacijske tehnologije u Republici Hrvatskoj. Za razliku od klasičnih teorija ekonomije baziranih na faktorima proizvodnje, kapitalu i radu; koncept „Nove ekonomije“ bazira se upravo na informacijskim i komunikacijskim tehnologijama gdje se podrazumijevaju poduzetništvo i inovativnost. Stoga, autori analiziraju IKT sektor u Hrvatskoj gdje se baziraju na proizvode. Naglašavaju porast udjela izvoza IKT-a u ukupnom izvozu, ali i brži rast uvoza od izvoza IKT proizvoda, što smatraju da i ne mora biti loše jer deficit IKT-a označava rastuće potrebe zemlje za novim tehnologijama. Međutim autori uočavaju da je udio IKT-a u ukupnom izvozu relativno nizak, posebice ako se usporedi s ostalim tranzicijskim zemljama. Ovaj sektor također promatraju i sa stajališta direktnih stranih ulaganja te zaključuju da je dosta privlačan stranim investitorima zbog tehnološke opremljenosti i monopolske pozicije.

Kovačević i Vuković (2006) analiziraju industrijske karakteristike vezane uz IKT sektor u Hrvatskoj i performanse poduzeća koja pripadaju u taj sektor. Iz prikazanih podataka autori zaključuju da većina IKT poduzeća u Hrvatskoj spada u grupu malih poduzeća, ali da su velika poduzeća značajnija u ostvarivanju tržišnih udjela. IKT sektor pokazuje veću profitabilnost od prosjeka hrvatskog gospodarstva. Također, vrlo je visoka stopa preživljavanja poduzeća, što se tumači time da je lakše preživjeti u brzorastućim industrijama jer se ulazak ne događa na štetu tržišnih udjela postojećih poduzeća, međutim ni broj ulazaka nije velik.

Martinović et al. (2014) prikazuju stanje IKT sektora u istočnoj Hrvatskoj te procjenjuju budući potencijal razvoja. Korištenjem ekonomskih IKT pokazatelja pokazuju potencijalno značajan utjecaj IKT sektora na gospodarski rast i produktivnost u gospodarstvu istočne Hrvatske. Uspoređuju BDP istočne Hrvatske s brojem IKT tvrtki, prosječnim plaćama i brojem širokopojasnih priključaka interneta. Iz prikazanih podataka autori zaključuju da je IKT sektor istočne Hrvatske slabije razvijen u odnosu na ostatak zemlje. Međutim smatraju da ima potencijal razvoja zbog cjenovnih prednosti relativno jeftinije radne snage, što bi moglo privući investitore uz uvjet da bi radna snaga postala konkurentnija.

Keček et al. (2016) analiziraju multiplicirajući učinak IKT sektora na slučaju Hrvatske u 2010. godine. Provode input - output analizu gdje je sustav gospodarstva podijeljen u nekoliko proizvodnih sektora, pri čemu se outputi svakog sektora gospodarstva koriste kao inputi za ostale sektore. Pokazali su da od svih djelatnosti iz IKT sektora najveći udio imaju telekomunikacijske usluge (oko $43 \%$ ). Nadalje, prikazuju vrijednosti multiplikatora pojedinih sektora prema Nacionalnoj klasifikaciji djelatnosti te zaključuju da je djelatnost „F - graditeljstvo“ najviše pridonijelo ekonomiji, a poslovanje nekretninama najmanje, dok je IKT na četvrtom mjestu. U IKT sektoru najveći multiplikator ima izdavačka djelatnost, a najniži usluge popravka računala i ostale opreme za kućanstvo. Kao razlog tomu autori 
navode brzo mijenjanje tehnologije, zbog čega se sve više korisnika odlučuje na kupnju nove opreme, a ne za popravak ili nadogradnju. Uspoređujući multiplikatore 2004. godine i 2010. godine autori nisu uočili značajne razlike. Kod usporedbe vrijednosti multiplikatora IKT sektora Hrvatske s odabranim zemljama EU, autori zaključuju da kod novih članica IKT ima manji doprinos.

Šebalj et al. (2017) procjenjuju mogućnosti za daljnji razvoj IT sektora istočne Hrvatske, analiziraju podatke o broju poduzeća i zaposlenosti od 2010. do 2014. godine s ciljem povećanja konkurentnosti te zadržavanja i privlačenja mladih i obrazovanih ljudi. Autori su pokazali da je lokalni IT sektor istočne Hrvatske slabije razvijen u odnosu na ostatak zemlje, a posebno u odnosu na sjeverozapadni dio. Međutim, iako je IT sektor slabije razvijen njegove su stope rasta veće u odnosu na ostatak zemlje, stoga autori očekuju njegov sve veći značaj u narednim godinama.

Keček et al. (2019) procjenjuju ukupni doprinos finalne potrošnje IKT proizvoda i usluga bruto dodanoj vrijednosti. Zaključuju da povećanje krajnje potražnje za IKT proizvodima i uslugama za jednu jedinicu utječe gotovo dvostruko na bruto dodanu vrijednost, dok je utjecaj na zaposlenost još i veći. Međutim, visok udio uvezenih IKT proizvoda i usluga od oko $40 \%$ u ukupnoj krajnjoj upotrebi ograničava potencijal za prelijevanje multiplikacijskih učinaka na domaće gospodarstvo. Autori su također pokazali da sve tri kategorije (kućanstva, neprofitne institucije i vlada) ukupne krajnje potrošnje na IKT-u imaju najveći doprinos bruto dodanoj vrijednosti. Razvoj domaćeg IKT sektora značajno poboljšava produktivnost cjelokupnog gospodarstva, dok svaka dodatno zaposlena osoba u IKT sektoru potiče otvaranje tri dodatna radna mjesta u ukupnom gospodarstvu i tako pomaže smanjenju nezaposlenosti. Rezultati pokazuju da Hrvatska zaostaje za razvijenim zemljama Europske unije u usvajanju novih tehnologija, slijedom čega je vidljiva ovisnost o uvozu osobito IKT proizvoda.

Psychoyios i Dotsis (2018) istražuju međunarodnu konkurentnost europskog IKT sektora. Kako bi se izmjerila konkurentnost u radu se koriste pokazatelji produktivnosti rada, troškovi istraživanja i razvoja i trgovinske performanse. Empirijskom analizom obuhvaćeno je 39 zemalja između 1999. i 2004. godine, rezultati su potvrdili hipotezu da EU ima bolje performanse u sektoru IKT usluga nego proizvoda.

Pužova i Marešova (2014) analiziraju stanje na češkom IKT tržištu. Prikazuju podjelu IKT poduzeća prema pretežitoj aktivnosti: proizvodnja, trgovina, usluge i telekomunikacije, iz čega zaključuju da dominiraju IKT usluge koje također imaju i najveću dodanu vrijednost. Dalje prikazuju odnos IKT uvoza i izvoza, pri čemu zaključuju da strane tvrtke predstavljaju veliku konkurenciju domaćih jer uvoz IKT-a raste u apsolutnom i relativnom smislu. Iako su zabilježili rast izvoza, i dalje uvoz nije pokriven izvozom. Smatraju da je potrebno osigurati stalan tijek ulaganja u istraživanje i razvoj jer proizvodi brzo zastarijevaju.

Malick i Chaudhary (2016) ispituju učinak IKT sektora robe i usluga na gospodarstvo Kine i Indije u razdoblju od 2000. do 2013. godine. Također procjenjuju izvoznu konkurentnost IKT sektora koristeći Balassanov indeks izražene komparativne prednosti engl. Revealed Comparative Advantage (RCA), izražene simetrične komparativne prednosti engl. Revealed Symmetric Comparative Advantage (RSCA) i indeks specijalizacije trgovine engl. Trade Specialisation Index (TSI). Rezultati su pokazali da Indija ima komparativnu prednost u IKT uslugama, a Kina u proizvodima, s time da je prednost Kine u proizvodima 
izraženija nego Indije u uslugama. Tendencije kretanja pokazatelja ukazuju na postupno smanjenje komparativne prednosti Indije u IKT uslugama. Autori smatraju da je doprinos Kine globalnim IKT uslugama ograničen zbog velike apsorpcije domaćeg tržišta, ali se komparativna prednost postupno povećava u promatranom razdoblju.

Ciriani i Perin (2017) analiziraju komparativne prednosti IKT sektora u tri glavne regije: Azija, EU28 i SAD, koji čine 90 \% svjetskog izvoza IKT robe i usluga. U izvozu IKT proizvoda dominira Azija, posebice Kina i „Četiri tigra“ s tendencijom rasta izvozne konkurentnosti. Azija i Kina imaju snažnu komparativnu prednost u IKT proizvodima, dok EU28 ima prednost u uslugama, no Kina to brzo sustiže. Raspodjela vrijednosti u svjetskim IKT tržištima naglašava dominaciju SAD-a u IT i softverskim uslugama te medijima, a Azija dominira u hardveru i elektronici. Sve u svemu, SAD se oslanja na globalni doseg svojih vodećih pružatelja usluga, dok se azijska dominacija odnosi na snažnu specijalizaciju u izvozu proizvoda. Glavna prednost EU28 leži u izvozu IKT usluga, a telekomunikacijske usluge su jedini segment u kojem ima značajan udio u svjetskim prihodima, ali stopa rasta je najniža od tri promatrane regije.

Kleibrink et al. (2018) prikazuju stanje IKT sektora Zapadnog Balkana s naglaskom na Srbiji. Iz prikazanih podataka uočavaju da je IKT najbrže rastući sektor u posljednjem desetljeću, a njegov udio u BDP-u Srbije iznosi $6 \%$. IKT sektor Srbije izvozno je orijentiran, posebice usluge s udjelom od $35 \%$ u ukupnom izvozu usluga. Dalje prikazuju broj zaposlenih u razdoblju od 2010. do 2015. godine, iz čega je vidljiv uzlazni trend (porast od $57 \%$ ). Što se tiče inovativnosti, autori su je izrazili pomoću udjela IKT patenata u ukupno prijavljenim patentima, pri čemu u Hrvatskoj imaju udio od $12 \%$, a u Srbiji $15 \%$, dok ostale zemlje regije imaju veće udjele. Na kraju zaključuju da IKT sektor ne treba gledati samo kao strateški sektor, već i kao na sredstvo za stvaranje pozitivnog prelijevanja na druge sektore i postizanje unakrsnih inovacija. Smatraju da Srbija još ima područja na kojima su joj potrebna poboljšanja, a ona se odnose na regulatorne, političke i obrazovne okvire.

Čorejova i Madudova (2019) istražuju utjecaj IKT sektora na prijenos znanja između sveučilišta i industrije, s naglaskom na Slovačku. Dodatno analiziraju konkurentnost IKT sektora zemalja OECD-a u razdoblju od 2000. do 2016. godine. Koriste deskriptivnu statistiku. Iz prikazanih podataka vidljiv je dominantan položaj IKT sektora usluga, na njega otpada $80 \%$ dodane vrijednosti ukupnog IKT sektora. IKT sektor ostaje ključni pokretač inovacija s više od $30 \%$ svih prijava patenata u zemljama OECD-a. Na osnovi različitih kategorija gospodarstva (razvijene zemlje, tranzicijske zemlje i zemlje u razvoju) autori uočavaju da tranzicijske zemlje zaostaju za ostalim u smislu udjela IKT sektora u uvozu i izvozu. Kada razmatraju širenje znanja, orijentiraju se na regionalni utjecaj u dugom razdoblju (od 1989. do 2016. godine). Shvaćaju da se razmjena znanja, a i orijentacija tvrtki, promijenila u navedenom razdoblju od odsustva interakcije na početku promatranog razdoblja pa u novije vrijeme do sve veće uloge koju imaju sveučilišta i udruge, posebice u jačanju regionalnog inovacijskog sustava i doprinosa umrežavanju.

Duc i Linh (2020) procjenjuju povezanost IKT sektora s vijetnamskim gospodarstvom te analiziraju multiplikacijski i međusektorski učinak. Zaključuju da vijetnamski IKT sektor ima mali doprinos BDP-u u odnosu na ostale sektore, ali naglašavaju sposobnost IKT sektora da se širi i stimulira druge sektore. Bez obzira na njegov mali output, IKT je značajan pokretač gospodarstva. 
Cioaca et al. (2020) ispituju utjecaj različitih IKT pokazatelja na ekonomski razvoj i nejednakost u Europskoj uniji od 2008. do 2018. godine. Autori su pronašli statistički značajnu povezanost između varijable pristup internetu i promjene BDP-a po stanovniku. Također, pronašli su negativnu vezu između varijable prijelaz na digitalno društvo (aproksimirane udjelom IKT-a u BDP-u) i zavisne varijable nejednakost raspodjele dohotka, naime povećanje od $1 \%$ udjela IKT sektora u BDP-u dovest će do smanjenja nejednakosti raspodjele dohotka od 0,27 \%. Zaključuju da napredak u digitalnom društvu smanjuje nejednakost raspodjele dohotka.

Fratto i Giannone (2020) ispituju utjecaj sigurnosnih mjera uvedenih za vrijeme bolesti COVID-19, koje smanjuju mobilnost ljudi i robe na različite sektore gospodarstva Zapadne obale, posebno na razvoj IKT sektora. U radu autori identificiraju različite kanale kroz koje promjene u pristupu tř̌ištu utječu na sektore gospodarstva. Zaključeno je da ograničenja u mobilnosti utječu na preraspodjelu resursa prema IKT sektoru, ali na mikrorazini ovisi o lokalnoj povezanosti s dobavljačima i kupcima. Autori preporučuju da se industrijska strategija usmjeri na skladan razvoj gospodarstva, umjesto na usmjeravanje na određeni sektor.

Mali broj istraživanja o konkurentnosti IKT sektora Hrvatske dovodi do nedostatka znanja o njegovoj relativnoj važnosti. Iako postoji nekoliko istraživanja o hrvatskom IKT sektoru ni jedno od njih nije obuhvatilo više pokazatelja i prikazalo pokrivenost uvoza i komparativnu prednost IKT sektora, posebno usluga, a posebno proizvoda. Inozemna istraživanja o konkurentnosti IKT sektora prikazuju komparativne prednosti, ali se uglavnom odnose na pojedinačne azijske zemlje ili cijele regije, međutim kod izračuna indeksa izražene komparativne prednosti neki od njih nisu provjerili ispunjenost Hillmanova uvjeta; primjerice Malick i Chaudhary (2016). Stoga ovo istraživanje doprinosi popunjavanju takvog jaza u literaturi.

Na temelju postavljenog cilja ovog rada, proučene literature te uočenih nedostataka i ograničenja, očekuje se da će ovaj rad pružiti doprinos prikazu konkurentnosti IKT sektora Hrvatske. S obzirom na to da je Hrvatska članica Europske unije, a time i dio zajedničkog tržišta, očekuje se slična struktura doprinosa IKT-a BDP-u kao što to imaju i ostale članice. Također, predviđa se podjednako kretanje trendova u promjeni izvoza IKT proizvoda i usluga Hrvatske i Europske unije te sličan udio izvoza IKT proizvoda u ukupnom robnom izvozu i IKT usluga u ukupnom izvozu usluga. Osim toga, ne očekuje se toliko značajna pokrivenost hrvatskog IKT uvoza izvozom. Očekuje se veća komparativna prednost kod sektora usluga nasuprot proizvoda, s tendencijom rasta kod oba.

\section{METODOLOGIJA: MJERENJE KONKURENTNOSTI I IZVOR PODATAKA}

Postoje dvije široke skupine pokazatelja za mjerenje konkurentnosti: pokazatelji usmjereni na rezultat (ex post pokazatelji) - temeljeni na podacima o trgovini i pokazatelji usmjereni na čimbenike (ex ante pokazatelji) - pravni i institucionalni okvir zemlje, infrastruktura i sl. (Pascucci, 2018).

S obzirom na to da je glavni cilj procijeniti izvoznu konkurentnost hrvatskog IKT sektora, odabiru se ex-post pokazatelji. Kao što je istaknuo Pascucci, (2018) ti su pokazate- 
lji prikladniji od ostalih za analizu konkurentnosti na razini industrije u Europskoj uniji. Temelje se na vidljivim dokazima koji se prvenstveno sastoje od podataka o trgovini, poput udjela pojedine industrije u izvozu, RCA indeksa i pokrivenosti uvoza. Svi ovi pokazatelji odražavaju prošle i aktualne performanse te tako daju značajne informacije o konkurentnosti određene industrije u određenom razdoblju. Budući da jedna dimenzija ne može obuhvaćati sve elemente konkurentnosti, koristi se višedimenzionalnost i multivarijabilnost. Polazeći od rada Malick i Chaudhary, (2016) konkurentske performanse IKT sektora mjerene su RCA indeksom na godišnjoj razini u razdoblju od 2005. do 2019. godine. Zbog određenih nedostataka RCA indeksa (asimetričnost na desnu stranu, vrijednost od 0 do $+\infty$ (Branković, 2015)), dodatno je izračunata njegova simetrična vrijednost kao što su to uradili Startinene i Remekiene (2013), Malick i Chaudhary (2016) te Pascucci (2018). Relevantnost dobivenog RCA indeksa u svakoj godini provjerena je izračunom Hillmanova uvjeta.

Osim toga prikazat ce se doprinos IKT-a BDP-u Hrvatske i 11 zemalja Europe od kojih Njemačka, Francuska, Italija i Ujedinjeno Kraljevstvo predstavljaju razvijene zemlje, a Bugarska, Češka, Mađarska, Rumunjska, Slovačka i Slovenija posttranzicijske zemlje. Također, prikazane su vrijednosti izvoza IKT-a u američkim dolarima (od 2005. do 2019. godine), stope promjene i trend kretanja (od 2000. do 2017. godine), udio IKT-a u ukupnom izvozu proizvoda i usluga (od 2005. do 2019.godine), te je izračunata pokrivenost uvoza IKT-a izvozom (posebno proizvodi i usluge od 2005. do 2019. godine)

Izvor podataka za istraživanje bilo je nekoliko baza podataka ovisno o dostupnosti pojedinih kategorija. Podaci o doprinosu IKT-a BDP-u preuzeti su iz Eurostata na godišnjoj razini u razdoblju od 2008. do 2017. godine. Godišnji podaci o izvoza IKT-a u izvozu usluga i robnom izvozu za razdoblje od 2000. do 2017. godine preuzeti su iz baze Svjetske banke (World Bank). Vrijednost izvoza pojedinih kategorija IKT usluga na godišnjoj razini u razdoblju od 2005. do 2019. godine preuzeta je iz International Trade Centrea, dok su za vrijednost izvoza IKT proizvoda podaci preuzeti iz baze United Nations Conference on Trade and Development.

\section{ANALIZA KONKURENTNOSTI IKT SEKTORA HRVATSKE}

Trenutno Državni zavod za statistiku (DZS) ne procjenjuje doprinos IKT sektora na nacionalnoj razini . Međutim, Eurostat (statistički ured Europske unije) daje podatke o doprinosu IKT sektora bruto domaćem proizvodu u posljednjem desetljeću, razvrstavajući posebno doprinos IKT proizvodnje i IKT usluga. Prema Statističkoj klasifikaciji ekonomskih aktivnosti (NACE, (trenutno na snazi NACE Rev.2)) Eurostat sumira podatke relevantnih ekonomskih aktivnosti koje ispunjavaju kriterije IKT-a. Prema tome, u IKT proizvodnju spada: proizvodnja elektroničkih komponenata, proizvodnja računala i periferne opreme, proizvodnja komunikacijske opreme, proizvodnja potrošačke elektronike i proizvodnja magnetskih i optičkih medija. U IKT usluge spada: trgovina na veliko IKT opremom, izdavanje softvera, telekomunikacije, računalno programiranje i savjetovanje te popravak računala i komunikacijske opreme (Eurostat, 2020). 
Grafikon 1. Godišnji doprinos informacijske i komunikacijske tehnologije bruto domaćem proizvodu Hrvatske u razdoblju od 2008. do 2017. godine

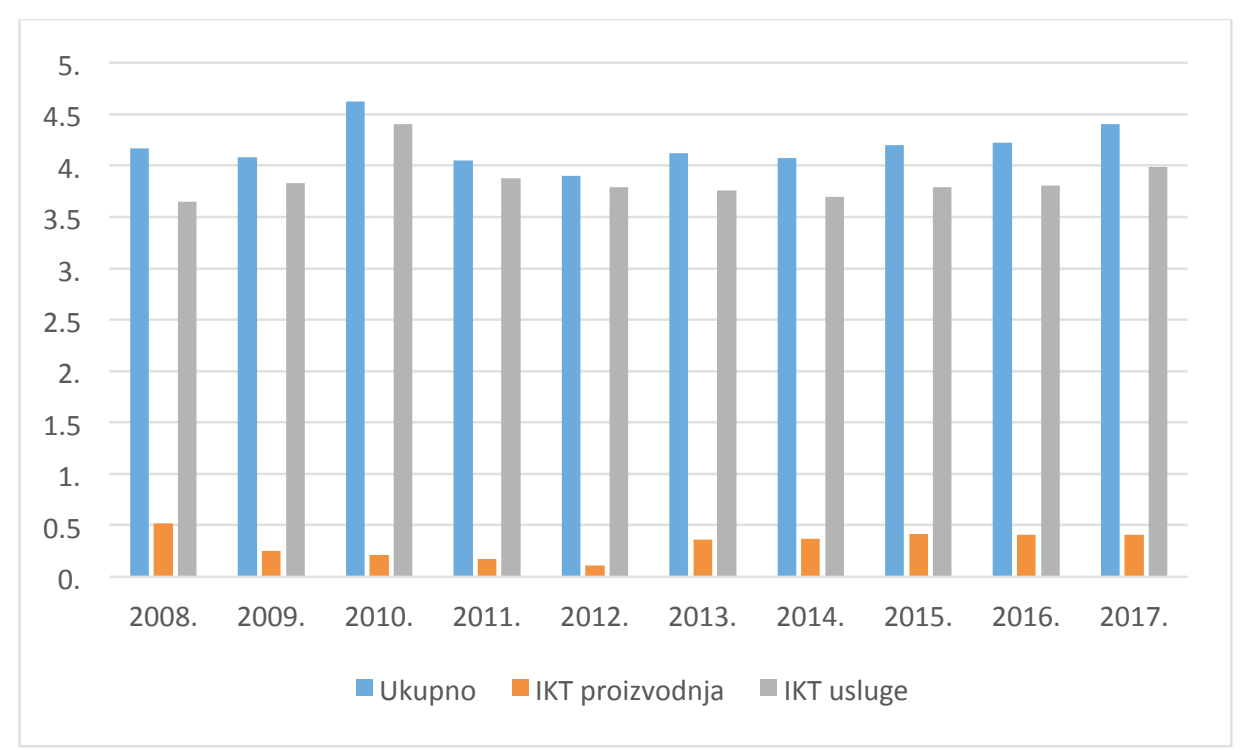

Izvor: izrada prema podacima Udio IKT sektora u BDP-u (Eurostat2020)

Iz grafikona 1 vidljivo je da se doprinos IKT sektora u razdoblju od 2008. do 2017. godine nije značajnije promijenio te da je stagnirao, pri čemu je najniža vrijednost bila 2012. godine $(3,9 \%)$ a najviša 2010 . godine $(4,62 \%)$, prvenstveno zbog porasta doprinosa IKT usluga. Nadalje, doprinos IKT proizvodnje tijekom promatranog razdoblja dosta je nizak i u promatranom se razdoblju smanjio. Najveća vrijednost bila je 2008. godine $(0,05 \%)$. Između ostalog, ovo samo naglašava veću važnost IKT usluga u BDP-u za hrvatsku ekonomiju.

Tablica 1. Doprinos informacijske i komunikacijske tehnologije BDP-u zemljama Europe u 2017. godini

\begin{tabular}{|l|c|c|c|}
\hline Zemlja & IKT usluge & IKT proizvodi & IKT ukupno \\
\hline Njemačka & 3,8 & 0,41 & 4,21 \\
\hline Francuska & 4,09 & 0,24 & 4,33 \\
\hline Italija & 3,09 & 0,24 & 3,33 \\
\hline Ujedinjeno Kraljevstvo & 5,76 & 0,20 & 5,96 \\
\hline Hrvatska & 3,99 & 0,41 & 4,4 \\
\hline Bugarska & 5,44 & 0,29 & 5,73 \\
\hline Češka & 4,06 & 0,36 & 4,42 \\
\hline Mađarska & 4,17 & 1,87 & 6,04 \\
\hline Rumunjska & 3,3 & 0,23 & 3,53 \\
\hline Slovačka & 3,67 & 0,64 & 4,31 \\
\hline Slovenija & 3,33 & 0,35 & 3,68 \\
\hline
\end{tabular}

Izvor: izrada prema podacima Udio IKT sektora u BDP-u (Eurostat, 2020) 
Što se tiče ukupnog doprinosa IKT-a BDP-u između razvijenih zemalja Europe i posttranzicijskih zemalja podaci su uglavnom slični; udio se kreće od $3 \%$ do $6 \%$ (tablica 1) $\mathrm{Na}$ temelju podataka vidi se da je glavni izvor doprinosa BDP-u od IKT usluga koje su u svim promatranim zemljama puno zastupljenije od IKT proizvoda. U skladu s tim može se reći da Hrvatska prati europski prosjek udjela pojedinih komponenti IKT-a u BDP-u.

Za razliku od Eurostata, International Trade Centre nema posebnu skupinu koju bi nazvao IKT proizvodnja ili usluge, međutim u podjeli usluga, skupina 9 (telekomunikacijske, računalne i informacijske usluge) mogla bi se smatrati IKT uslugama jer u najvećoj mjeri odgovara definiciji IKT-a, dok kod proizvoda nema tako istaknute skupine koja bi se mogla smatrati reprezentativnom za IKT sektor. Prema International Trade Centre (2020.a) u skupinu 9 spadaju: 1. telekomunikacijske usluge, 2. računalne usluge koje se dijele na softverske usluge i ostale računalne usluge osim softverskih i 3. informacijske usluge koje se dijele na izvještajne usluge i ostale informacijske usluge osim izvještajnih.

Tablica 2. Doprinos informacijske i komunikacijske tehnologije izvozu Hrvatske, promjena 2005. - 2019. g.

\begin{tabular}{|l|r|r|r|}
\hline \multicolumn{1}{|c|}{ Godina } & \multicolumn{1}{c|}{2005.} & \multicolumn{1}{c|}{2019.} & Promjena \\
\hline IKT proizvodi u robnom izvozu & $3,05 \%$ & $2,77 \%$ & $-0,27 \%$ \\
\hline IKT usluge u izvozu usluga & $3,47 \%$ & $5,68 \%$ & $2,20 \%$ \\
\hline Telekomunikacijske usluge u IKT uslugama & $74,32 \%$ & $20,19 \%$ & $-54,13 \%$ \\
\hline Računalne usluge u IKT uslugama & $25,55 \%$ & $76,25 \%$ & $50,70 \%$ \\
\hline Informacijske usluge u IKT uslugama & $0,14 \%$ & $3,56 \%$ & $3,42 \%$ \\
\hline
\end{tabular}

Izvor: izračun autora prema podacima iz Popisa zemalja uvoznica za izvezene usluge hrvatskog sektora usluga: 9 - Telekomunikacijske, računalne i informacijske usluge (International Trade Centre, 2020. a), Popis zemalja uvoznica za izvezene usluge hrvatskog sektora usluga: - Sve usluge (International Trade Centre, 2020. b), Izvoz IKT proizvoda (United Nations Conference on Trade and Development, 2020. a) i Izvoz i uvoz roba i usluga, Hrvatska/svijet (United Nations Conference on Trade and Development, 2020. b)

U promatranom razdoblju od 2005. do 2019. godine izvoz usluga Hrvatske je prema International Trade Centreu porastao. Paralelno s rastom ukupnog izvoza rastao je i izvoz IKT-a, ali po bržim stopama od rasta ukupnog izvoza usluga (Tablica 2). Posljedično, udio IKT usluga u izvozu porastao je za 2,2 postotna boda te u 2019. godini iznosi 5,68 \%. Važno je uočiti promjene u strukturi izvoza IKT usluga gdje su u promatranom razdoblju računalne i telekomunikacijske usluge gotovo zamijenile mjesta; porast udjela računalnih usluga za 50,7 postotnih bodova nasuprot padu telekomunikacijskih usluga za 54,13 postotnih bodova. Udio IKT proizvoda u robnom izvozu smanjio se za $0,27 \%$. te u 2019. iznosi $2,77 \%$ robnog izvoza

Na grafikonu 2 prikazane su vrijednosti izvoza IKT usluga u razdoblju od 2005. do 2019. godine. 
Grafikon 2. Vrijednost izvoza IKT usluga Hrvatske u razdoblju od 2005. do 2019. godine u milijunima dolarima

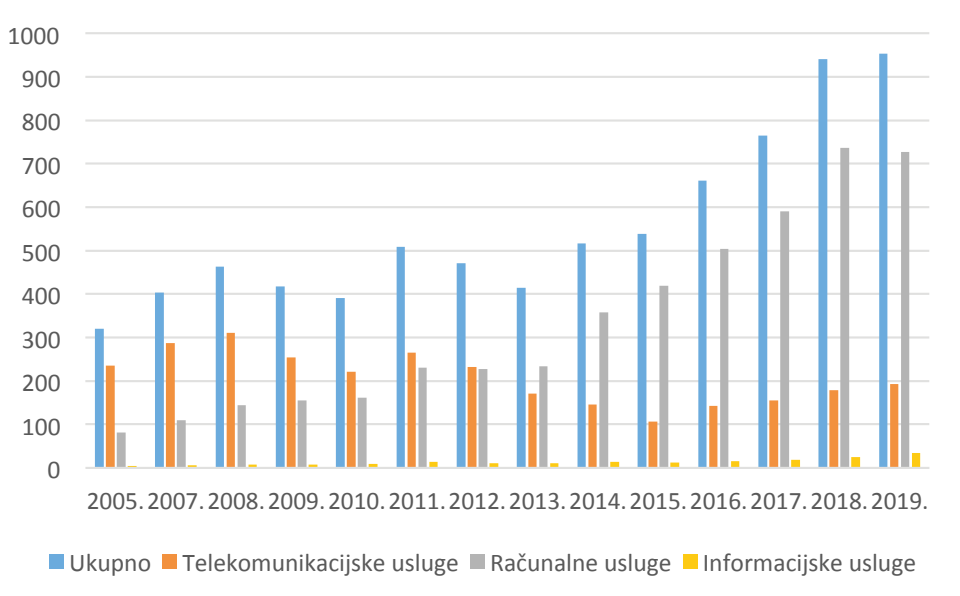

Izvor: izrada prema podacima iz Popisa zemalja uvoznica za izvezene usluge hrvatskog sektora usluga: 9 -Telekomunikacijske, računalne i informacijske usluge (International Trade Centre, 2020. a)

Iz grafikona 2 može se vidjeti da se vrijednost izvoza IKT usluga gotovo utrostručila u promatranom razdoblju. To je uglavnom zbog rasta vrijednosti izvoza računalnih usluga, posebice nakon 2014. godine. Tendencija kretanja telekomunikacijskih usluga ukazuje na pad njihove važnosti, dok informacijske usluge bilježe stope rasta, ali je njihov udio vrlo mali. Podaci o IKT proizvodima uzeti su iz baze podataka United Nations Conference on Trade and Development. Prema njima u IKT proizvode spadaju: računala i periferna oprema, komunikacijska oprema, potrošačka elektronika, elektroničke komponente i ostala IKT oprema. Grafikon 3 prikazuje vrijednost izvoza IKT proizvoda, može se uočiti postupan pad u sredini promatranog razdoblja te postupan rast posljednjih godina promatranog razdoblja. Izvoz IKT proizvoda gotovo je tri puta manji od izvoza IKT usluga.

Grafikon 3. Vrijednost izvoza IKT proizvoda Hrvatske u razdoblju od 2005. do 2019. godine u milijunima dolarima

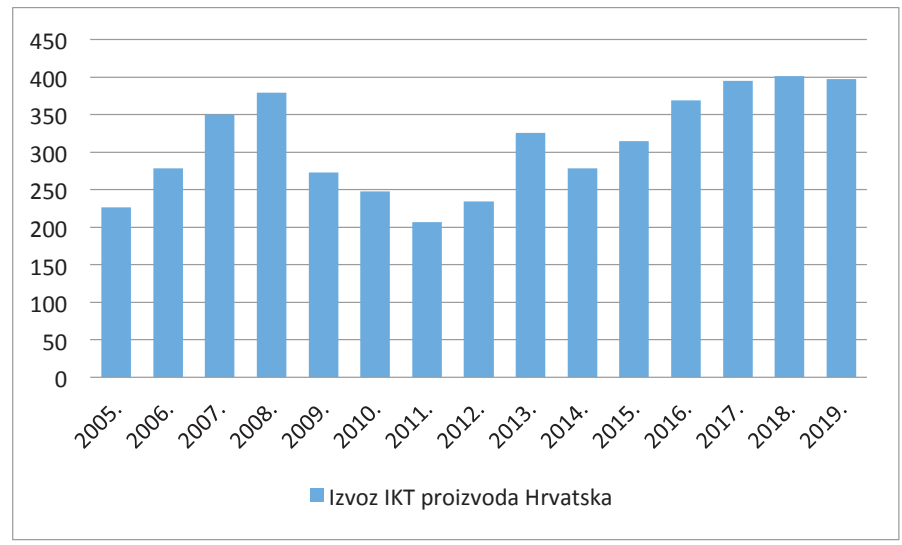

Izvor: izrada prema podacima Izvoz IKT proizvoda (United Nations Conference on Trade and Development, 2020. a) 
Kao što je već utvrđeno relativni doprinos IKT proizvoda u gospodarstvu Hrvatske smanjuje se, dok doprinos IKT usluga raste. Iz grafikona 4 može se uočiti suprotnost u kretanju udjela IKT proizvoda i usluga u razdoblju od 2008. do 2014. kad je udio IKT usluga rastao, udio proizvoda je padao i obrnuto.

Grafikon 4. Udio IKT proizvoda u ukupnom robnom izvozu i udio IKT usluga u ukupnom izvozu usluga od 2005. do 2019. godine.

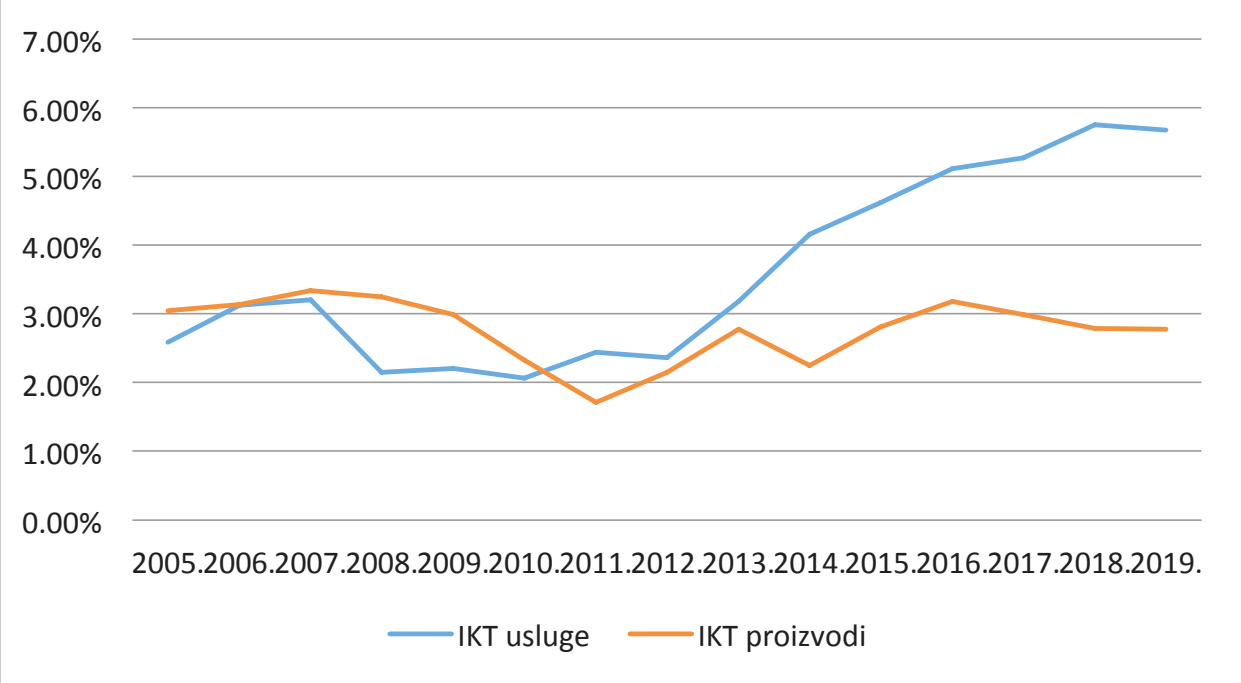

Izvor: izrada prema podacima iz Izvoz IKT proizvoda (United Nations Conference on Trade and Development, 2020. a), Izvoz i uvoz roba i usluga, Hrvatska/svijet (United Nations Conference on Trade and Development, 2020. b), Popis zemalja uvoznica za izvezene usluge hrvatskog sektora usluga: 9 - Telekomunikacijske, računalne i informacijske usluge (International Trade Centre, 2020. a) i Popis zemalja uvoznica za izvezene usluge hrvatskog sektora usluga: - Sve usluge

Podaci o pojedinim zemljama nedostaju u bazi United Nations Conference on Trade and Development, stoga su za usporedbu Hrvatske s odabranim zemljama Europe korišteni podaci Svjetske Banke. Pod proizvode IKT-a Svjetska Banka ubraja: računala i perifernu opremu, komunikacijsku opremu, potrošačku elektroniku, elektroničke komponente i ostalu informacijsku i tehnološku robu. Softver općenito ne uključuju u skupinu proizvoda, međutim svjesni su činjenice da je ponekad teško isključiti vrijednost softvera kad je on ugrađen u određeni uređaj (World Bank, 2020. b). Pod IKT usluge Svjetska Banka ubraja: računalne i komunikacijske usluge (telekomunikacijske, poštanske i kurirske usluge) i informacijske usluge (transakcije računalnih podataka i usluga informiranja) (World Bank, 2020. a).

Udio izvoza IKT usluga u ukupnom izvozu usluga na razini Europske unije prema podacima Svjetske banke iznosio je u 2017. godini 12,7 \%. Uspoređujući navedeno s Hrvatskom (5,2 \%) može se zaključiti da se ipak radi o značajnijem udjelu. Udio izvoza IKT usluga u Hrvatskoj u 2000. godine bio je niži od razvijenih zapadnih zemalja. Međutim, izuzev Rumunjske, u skladu je s ostalim posttranzicijskim zemljama. Promjene koje su se dogodile u narednih petnaestak godina dovele su do toga da su sve promatrane zemlje izuzev Francuske doživjele porast udjela 
izvoza IKT usluga. Nadalje, uspoređujući udio Hrvatske s razvijenim zemljama njezin se udio manje povećao. Dodatnom usporedbom s povijesno politički usporedivim posttranzicijskim zemljama, vidljivo je da za razliku od 2000. godine u 2017. godini Hrvatska ima dosta mali udio izvoza IKT usluga, tj. nije doživjela toliki rast kao ostale posttranzicijske zemlje.

Tablica 3. Usporedba promjena udjela izvoza IKT usluga u ukupnom izvozu usluga u zemljama Europe u razdoblju od 2000. do 2017. godine

\begin{tabular}{|l|r|r|r|}
\hline Zemlja/Godina & 2000. & 2017. & Promjena \\
\hline Njemačka & 6,24 & 11,70 & 5,46 \\
\hline Francuska & 7,17 & 6,75 & $-0,42$ \\
\hline Italija & 5,83 & 8,10 & 2,28 \\
\hline Švedska & 8,71 & 19,13 & 10,42 \\
\hline Ujedinjeno Kraljevstvo & 4,33 & 7,05 & 2,72 \\
\hline Hrvatska & 3,07 & 5,20 & 2,14 \\
\hline Bugarska & 2,31 & 12,31 & 9,99 \\
\hline Češka & 2,02 & 14,02 & 12,00 \\
\hline Mađarska & 2,55 & 8,19 & 5,64 \\
\hline Rumunjska & 10,73 & 18,13 & 7,40 \\
\hline Slovačka & 4,61 & 14,61 & 10,00 \\
\hline Slovenija & 4,05 & 7,43 & 3,38 \\
\hline Europska unija & 5,59 & 12,69 & 7,10 \\
\hline
\end{tabular}

Izvor: izrada prema podacima iz Izvoza IKT usluga (kao postotak ukupnog izvoza usluga) (World Bank 2020. a)

Iako se u relativnom udjelu izvoza IKT usluga Hrvatska razlikuje od Europske unije, tendencija kretanja Hrvatske uglavnom prati trendove EU-a prvih promatranih deset godina (grafikon 5), dok se od 2012. trendovi razilaze. Europska je unija prvo doživjela snažan pad u 2015. godini, ali već sljedećih godina bilježi još veće stope rasta.

Grafikon 5. Usporedba kretanja promjena izvoza IKT usluga Hrvatske i Europske unije u razdoblju od 2000. do 2017. g. (t-1)

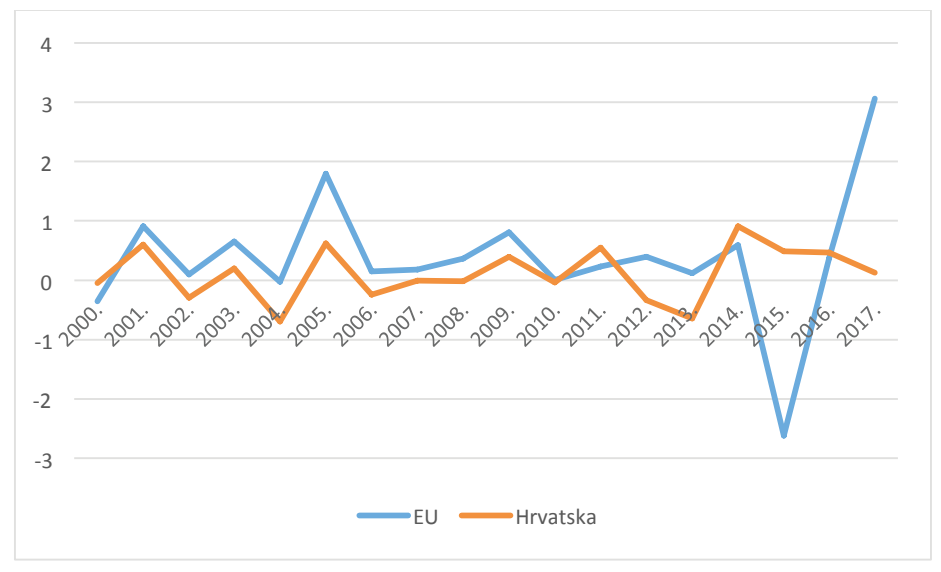

Izvor: izrada prema podacima iz Izvoza IKT usluga (kao postotak ukupnog izvoza usluga) (World Bank 2020. a) 
U tablici 4 sadržani su statistički podaci o udjelu izvoza IKT proizvoda zemalja odabranih zemalja Europe u 2000. godini i 2017. godini, a prikazana je i apsolutna promjena između te dvije godine. Za razliku od sektora IKT usluga, u ovoj tablici vidljive su veće varijacije u podacima. Primjerice, udio u 2000. godini varira od 0,8\% u Bugarskoj do 25,7\% u Mađarskoj. Jedino zajedničko kod razvijenih zemalja jest pad udjela izvoza IKT proizvoda, dok su kod posttranzicijskih zemalja rezultati oprečni. Što se tiče Hrvatske, udio je nizak i nije se značajnije promijenio; najsličnije susjednoj Sloveniji.

Tablica 3. Usporedba promjena udjela izvoza IKT proizvoda u ukupnom robnom izvozu zemalja Europe u razdoblju od 2000. do 2017. godine

\begin{tabular}{|l|r|r|c|}
\hline Zemlja/Godina & 2000. & 2017. & Promjena \\
\hline Njemačka & 8,40 & 4,96 & $-3,45$ \\
\hline Francuska & 10,81 & 3,93 & $-6,87$ \\
\hline Italija & 4,45 & 1,90 & $-2,55$ \\
\hline Švedska & 17,73 & 6,07 & $-11,66$ \\
\hline Ujedinjeno Kraljevstvo & 17,47 & 4,25 & $-13,22$ \\
\hline Hrvatska & 1,99 & 2,51 & 0,52 \\
\hline Bugarska & 0,79 & 2,75 & 1,96 \\
\hline Češka & 4,59 & 13,33 & 8,74 \\
\hline Mađarska & 25,74 & 11,18 & $-14,56$ \\
\hline Rumunjska & 4,99 & 2,99 & $-2,00$ \\
\hline Slovačka & 3,29 & 16,35 & 13,06 \\
\hline Slovenija & 1,94 & 1,83 & $-0,11$ \\
\hline Europska unija & 10,08 & 5,34 & $-4,74$ \\
\hline
\end{tabular}

Izvor: izrada prema podacima iz Izvoza IKT proizvoda (kao postotak ukupnog robnog izvoza) (World Bank, 2020. b)

Grafikon 6 prikazuje apsolutnu promjenu u odnosu na prethodno razdoblje te podupire zaključke prethodno analizirane tablice. Naime u tablici 3 prikazana je apsolutna promjena 2000. godine i 2017. godine, gdje je vidljivo da je raspon promjena vrlo velik u nekim zemljama i varira od smanjenja za 14 postotnih bodova do porasta za 13 postotnih bodova. Slično tome, trend kretanja izvoza IKT proizvoda u Hrvatskoj ne prati promjene u Europskoj uniji; jedina zajednička činjenica u trendovima je ta da nema ekstremne promjene iz razdoblja u razdoblje tj. kreće se u jednom postotnom bodu. 
Grafikon 6. Usporedba kretanja promjena izvoza IKT proizvoda Hrvatske i Europske unije u razdoblju od 2001. do 2017. godine

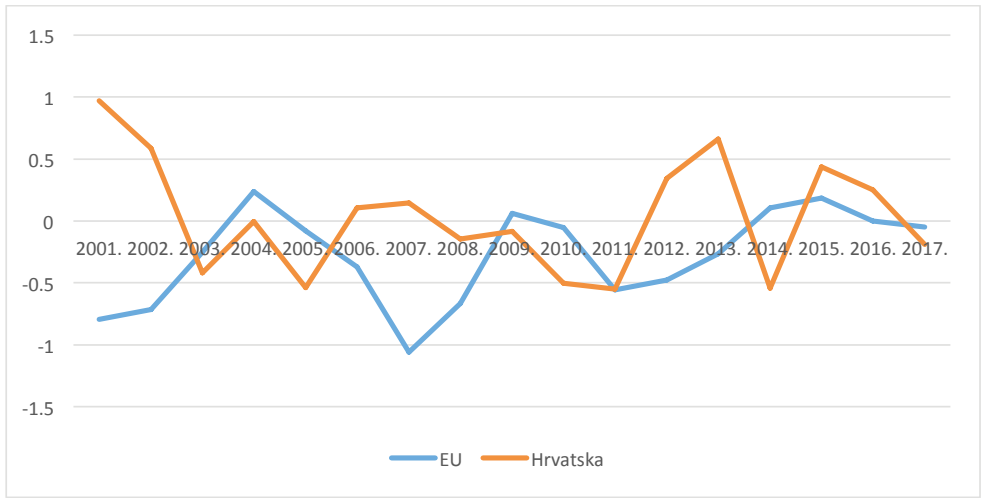

Izvor: izrada prema podacima iz Izvoza IKT proizvoda (kao postotak ukupnog robnog izvoza) (World Bank, 2020. b)

Koristan pokazatelj koji mjeri sposobnost konkuriranja zemlje na svjetskom tržištu jest pokrivenost uvoza izvozom. Pokazatelj pokrivenost uvoza izvozom često je korišten način određivanja konkurentnosti. Pokrivenost uvoza IKT usluga izvozom pokazuje konkurentnost hrvatskog IKT sektora usluga. Računa se kao omjer izvoza IKT sektora usluga prema uvozu. Analiza tog pokazatelja polazi od činjenice da je pozitivna trgovinska bilanca posljedica nižih troškova i/ili nekih necjenovnih faktora u odnosu na zemlju uvoznika.

Grafikon 7. Pokrivenost uvoza IKT usluga izvozom u Hrvatskoj

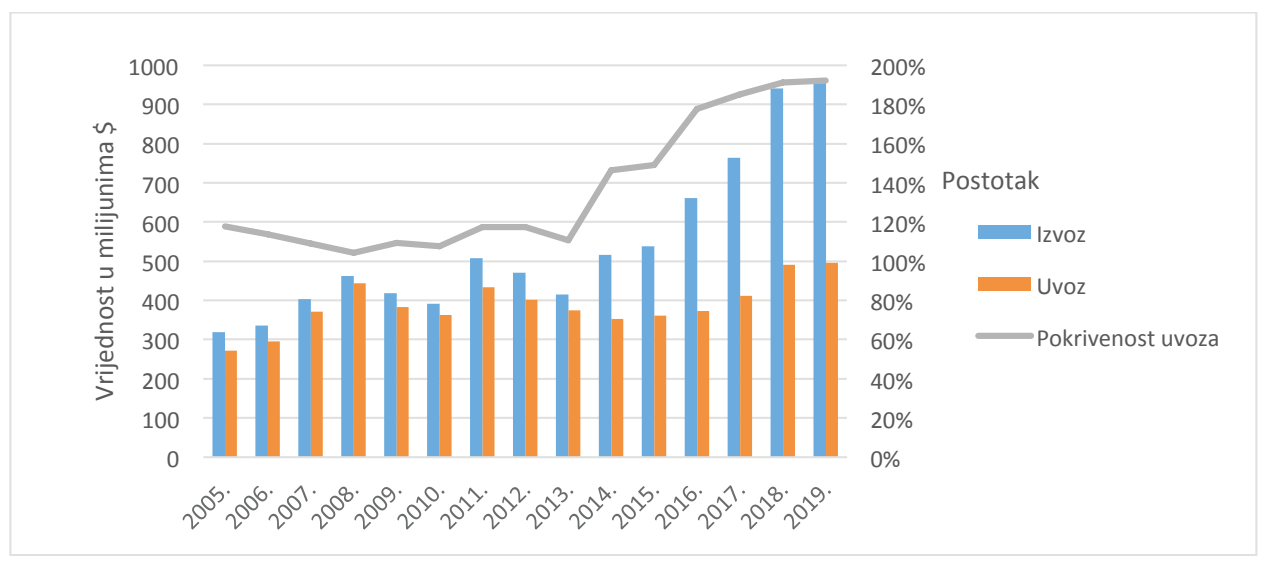

Izvor: izrada prema podacima iz Popisa zemalja uvoznica za izvezene usluge hrvatskog sektora usluga: 9 - Telekomunikacijske, računalne i informacijske usluge (International Trade Centre, 2020. a) i Popisa zemalja opskrbnog tržišta usluga za Hrvatsku: 9 - Telekomunikacijske, računalne i informacijske usluge (International Trade Centre, 2020. c)

Grafikon 7 prikazuje vrijednost izvoza i uvoza u tisućama dolara (stupčasti grafikon) i postotak pokrivenosti uvoza izvozom (linijski grafikon) u Hrvatskoj u razdoblju od 2005. do 2019. godine. Iz prikazanog grafikona vidljivo je da je hrvatski IKT sektor usluga kon- 
kurentan jer je pokazatelj pokrivenost uvoza izvozom veći od 1, tj. od $100 \%$, što znači da se izvozi više nego uvozi. Također, pozitivno je što navedeni pokazatelj raste posljednjih šest godina, kao i činjenica da do njegova porasta nije došlo zbog pada uvoza (znači da i dalje postoji domaća potražnja) već zbog porasta izvoza. S druge strane, uvoz IKT proizvoda nije pokriven izvozom. Na grafikonu 8 vidljivo je da iznosi nešto manje od $30 \%$ u 2019. godini. Prema tome, može se zaključiti da hrvatski IKT sektor proizvoda nije konkurentan, iako se pokazatelj poboljšao od početka promatranog razdoblja.

Grafikon 8. Pokrivenost uvoza IKT proizvoda izvozom u Hrvatskoj

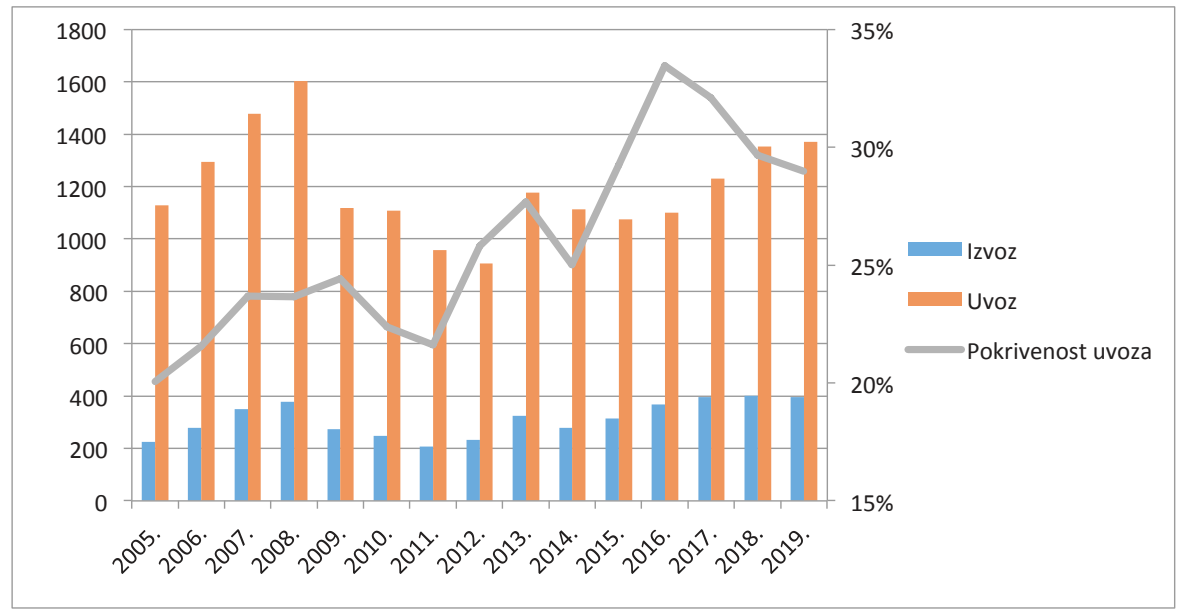

Izvor: izrada prema podacima Izvoz IKT proizvoda (United Nations Conference on Trade and Development, 2020. a) i Uvoz IKT proizvoda, Hrvatska (United Nations Conference on Trade and Development, 2020. c)

Komparativna prednost uobičajeno se izražava indeksom izražene komparativne prednosti, engl. Revealed Comparative Advantage (RCA) kreiranim od Balassa (1965). Ovo je uobičajena metoda procjene komparativne prednosti (Malick i Chaudhary, 2016 i Pascucci, 2018), utemeljena na konvencionalnoj teoriji trgovine, a temelji se na mjerenju izvozne specijalizacije zemlje. Indeks izražene komparativne prednosti izračunat je po formuli:

$$
R C A=\frac{X_{i j} / X_{n j}}{X_{i t /} / X_{n t}}
$$

pri čemu je:

$\mathrm{X}_{\mathrm{ij}}$ - izvoz proizvoda ,i“"zemlje ,j“,

$X_{i t}$ - svjetski izvoz proizvoda ,i“,

$X_{\text {nj }}$ - ukupan izvoz zemlje , ,j“,

$\mathrm{X}_{\mathrm{nt}}$ - ukupan svjetski izvoz.

RCA indeks mjeri komparativnu prednost u izvozu robe „„“ zemlje ,j“. U situaciji kad je vrijednost veća od 1 , onda analizirana zemlja ima izražene komparativne prednosti u izvozu konkretne robe. Suprotno, ako je vrijednost manja od 1, onda je evidentan nedostatak komparativne prednosti u izvozu konkretne robe. Ovim indeksom prikazuje se stanje ekonomije za- 
jedno s ekspanzijom pojedinih proizvoda u kojima postoji tržišni potencijal. Osim toga, može se dobiti uvid o perspektivi i potencijalu vanjskotrgovinske razmjene (Stojanov et al. 2011).

Kako bi se RCA indeks mogao primijeniti u teorijskim pretpostavkama komparativne prednosti, Hillman (1980) je definirao uvjet (u literaturi poznat kao Hillmanov uvjet) da RCA indeks zadovoljava pretpostavku prema kojoj zemlja pokazuje komparativnu prednost kod onih proizvoda kod kojih su autarkične cijene niže od cijena u uvjetima slobodne trgovine. Općenito, to će pravilo biti zadovoljeno ako promatrana zemlja nema pretjerano velik udio u svjetskom izvozu promatranog proizvoda, a promatrani proizvod nema velik udio u ukupnom izvozu zemlje (Branković, 2015). Konkretno, Hillmanov uvjet definira se:

pri čemu je:

$$
1-\frac{X_{i j}}{X_{i t}}>\frac{X_{\mathrm{ij}}}{X_{\mathrm{nj}}}\left(1-\frac{\mathrm{X}_{\mathrm{nj}}}{\mathrm{X}_{\mathrm{nt}}}\right)
$$

$X_{\mathrm{ij}}-\mathrm{izvoz}$, ,proizvoda ,i“" zemlje ,j“",

$\mathrm{X}_{\mathrm{it}}$ - svjetski izvoz proizvoda ,i“,

$X_{n j}-$ ukupan izvoz zemlje , j“,

$\mathrm{X}_{\mathrm{nt}}$ - ukupan svjetski izvoz.

Primjena date nejednakosti na podatke korištene u ovom radu pokazuje da je Hillmanov uvjet ispunjen u svim godinama promatranog razdoblja kako za IKT proizvode tako i za usluge.

Tablica 5: Hillmanov uvjet

\begin{tabular}{|c|c|c|c|c|}
\hline Godina & \multicolumn{2}{|c|}{ IKT proizvodi } & \multicolumn{2}{c|}{ IKT usluge } \\
\hline & $1-\left(X \_i j / X \_i t\right)$ & $\begin{array}{c}\text { X_ij/X_nj*(1-(X_- } \\
\text { nj/X_nt)) }\end{array}$ & $1-\left(X \_i j / X \_i t\right)$ & $\begin{array}{c}\text { X_ij/X_nj*(1-(X_ } \\
\text { nj/X_nt)) }\end{array}$ \\
\hline 2005. & 0,999827 & 0,030451 & 0,995255 & 0,025826 \\
\hline 2006. & 0,999814 & 0,031308 & 0,995487 & 0,031162 \\
\hline 2007. & 0,999779 & 0,033418 & 0,995518 & 0,031997 \\
\hline 2008. & 0,999769 & 0,032483 & 0,997011 & 0,021413 \\
\hline 2009. & 0,999805 & 0,029863 & 0,998128 & 0,021987 \\
\hline 2010. & 0,999856 & 0,023278 & 0,998486 & 0,020594 \\
\hline 2011. & 0,999886 & 0,017119 & 0,998181 & 0,024323 \\
\hline 2012. & 0,999874 & 0,021466 & 0,998599 & 0,023560 \\
\hline 2013. & 0,999831 & 0,027806 & 0,998945 & 0,031746 \\
\hline 2014. & 0,999860 & 0,022520 & 0,998905 & 0,041498 \\
\hline 2015. & 0,999838 & 0,028082 & 0,998871 & 0,046128 \\
\hline 2016. & 0,999806 & 0,031855 & 0,998666 & 0,050991 \\
\hline 2017. & 0,999815 & 0,029940 & 0,998579 & 0,052614 \\
\hline 2018. & 0,999828 & 0,027860 & 0,998489 & 0,057348 \\
\hline 2019. & 0,999826 & 0,027713 & 0,998546 & 0,056624 \\
\hline
\end{tabular}

Izvor: izračun prema podacima Popis zemalja uvoznica za izvezene usluge hrvatskog sektora usluga: 9 - Telekomunikacijske, računalne i informacijske usluge (International Trade Centre, 2020. a), Popis zemalja uvoznica za izvezene usluge hrvatskog sektora usluga: - Sve usluge (International Trade Centre, 2020. b), Popis zemalja izvoznica usluga: Sve usluge (International Trade Centre, 2020. d), Popis zemalja izvoznica usluga: - Telekomunikacijske, računalne i informacijske usluge, (International Trade Centre, 2020. e), Izvoz IKT proizvoda (United Nations Conference on Trade and Development, 2020. a) i Izvoz i uvoz roba i usluga, Hrvatska/svijet (United Nations Conference on Trade and Development, 2020. b) 
Zbog određenih nedostataka RCA indeksa, uz njega se često koristi i indeks izražene simetrične komparativne prednosti, engl. Revealed Symmetric Comparative Advantage (RSCA) koji je simetrična vrijednost RSCA (Pascucci, 2018). RSCA indeks izražava se sljedećom formulom:

$$
R S C A=\frac{(R C A-1)}{(R C A+1)}
$$

Vrijednost se kreće između -1 i 1, ako je vrijednost pozitivna, zemlja ima komparativnu prednost, a ako je negativna to označava komparativni nedostatak (Malick i Chaudhary, 2016).

Tablica 6: Komparativna prednost hrvatskog IKT sektora

\begin{tabular}{|c|c|c|c|c|}
\hline \multirow{2}{*}{ Godina } & \multicolumn{2}{|c|}{ IKT proizvodi } & \multicolumn{2}{c|}{ IKT usluge } \\
\cline { 2 - 5 } & RCA & RSCA & RCA & RSCA \\
\hline 2005. & 0,24 & $-0,62$ & 1,35 & 0,15 \\
\hline 2006. & 0,25 & $-0,61$ & 1,28 & 0,12 \\
\hline 2007. & 0,29 & $-0,55$ & 1,27 & 0,12 \\
\hline 2008. & 0,31 & $-0,52$ & 0,83 & $-0,09$ \\
\hline 2009. & 0,26 & $-0,59$ & 0,58 & $-0,26$ \\
\hline 2010. & 0,20 & $-0,66$ & 0,55 & $-0,29$ \\
\hline 2011. & 0,17 & $-0,71$ & 0,65 & $-0,21$ \\
\hline 2012. & 0,21 & $-0,65$ & 0,57 & $-0,27$ \\
\hline 2013. & 0,27 & $-0,58$ & 0,40 & $-0,43$ \\
\hline 2014. & 0,21 & $-0,65$ & 0,46 & $-0,37$ \\
\hline 2015. & 0,23 & $-0,62$ & 0,48 & $-0,35$ \\
\hline 2016. & 0,26 & $-0,58$ & 0,52 & $-0,31$ \\
\hline 2017. & 0,24 & $-0,61$ & 0,54 & $-0,30$ \\
\hline 2018. & 0,23 & $-0,63$ & 0,55 & $-0,29$ \\
\hline 2019. & 0,23 & $-0,63$ & 0,53 & $-0,31$ \\
\hline
\end{tabular}

Izvor: izračun prema podacima Popis zemalja uvoznica za izvezene usluge hrvatskog sektora usluga: 9 - Telekomunikacijske, računalne i informacijske usluge (International Trade Centre, 2020. a), Popis zemalja uvoznica za izvezene usluge hrvatskog sektora usluga: - Sve usluge (International Trade Centre, 2020. b), Popis zemalja izvoznica usluga: Sve usluge (International Trade Centre, 2020. d), Popis zemalja izvoznica usluga: - Telekomunikacijske, računalne i informacijske usluge, (International Trade Centre, 2020. e),Izvoz IKT proizvoda (United Nations Conference on Trade and Development, 2020. a) i Izvoz i uvoz roba i usluga, Hrvatska/svijet (United Nations Conference on Trade and Development, 2020. b)

Tablica 6 prikazuje RCA i RSCA indekse IKT sektora proizvoda i usluga. Kada se razmatra komparativna prednost IKT sektora usluga tablica omogućava podjelu na dva razdoblja: (1.) prve tri godine promatranog razdoblja su uspješne s RCA indeksom većim od 1 i RSCA većim od nule, što je ukazivalo na određene komparativne prednosti Hrvatske. (2.) 2008. godine dolazi do značajnog pogoršanja vrijednosti ovih pokazatelja te oni padaju ispod 1 (RCA) odnosno ispod nule (RSCA), što označava da je Hrvatska izgubila komparativ- 
nu prednost. Kao posljedica postavlja se pitanje: koje su je zemlje dobile u istom razdoblju? U 2009. godini pokazatelji se još smanjuju, a nakon toga, pa sve do kraja promatranog razdoblja nastupa stagnacija. Što se tiče IKT proizvoda iz tablice je vidljivo da Hrvatska u njima nema komparativnu prednost te njihove vrijednosti stagniraju tijekom cijelog promatranog razdoblja. Uspoređujući sektore proizvoda i usluga ipak se može uočiti da usluge imaju nešto bolju komparativnu prednost u odnosu na proizvode.

\section{DISKUSIJA REZULTATA}

Provedenom analizom podataka iz različitih baza potvrdio se značaj IKT proizvoda i usluga za gospodarstvo Hrvatske. Na temelju dostupnih podataka može se vidjeti da se nominalna vrijednost IKT izvoza usluga Hrvatske povećala tri puta u razdoblju od 2005. do 2019. godine i to zbog rasta računalnih usluga. Također je utvrđeno da se relativni doprinos IKT proizvoda izvozu smanjuje, dok doprinos IKT usluga raste. Kao i u Hrvatskoj i u ostalim zemljama Europe IKT usluge čine veći udio BDP-a nego što je to slučaj kod IKT proizvoda. Slično tome, veću važnost sektora IKT usluga na razini cijele Europe potvrdili su Psychoyios i Dotsis (2018).

Prikazani podaci uspjeli su dati odgovor na istraživačka pitanja postavljena u uvodnom dijelu rada. Doprinos IKT sektora BDP-u Hrvatske u promatranom razdoblju od 2008. do 2017. godine stagnira te uglavnom iznosi oko $4 \%$ te potvrđuje očekivanja o kretanju u skladu s europskim trendovima. Sukladno očekivanjima da u strukturi samog IKT sektora dominiraju usluge kao što su za Češku potvrdili Pužova i Marešova (2014), a za Slovačku Čorejova i Madudova (2019), to se u ovom radu potvrdilo i za Hrvatsku. IKT usluge svoju su vrijednost u posljednjih 15 godina utrostručile, a proizvodi su vrlo malo zastupljeni u cijelom razdoblju. Unutar IKT usluga najznačajnije su računalne usluge, a zatim slijede telekomunikacijske i informacijske usluge.

Uspoređujući udio izvoza IKT usluga Hrvatske u razdoblju od 2000. do 2017. godine s prosjekom Europske unije, vidljivo je njegovo zaostajanje. Taj zaostatak je relativno još i veći ako ga se usporedi samo s posttranzicijskim zemljama koje su u početku imale vrlo niske udjele. Iako se očekivao približno isti udio izvoza IKT-a Hrvatske barem s posttranzicijskim zemljama, ta se očekivanja nisu potvrdila. Ova očekivanja bazirala su se na sličnim gospodarsko-političkim prilikama koje su vladale u tim zemljama te se smatralo da bi prema tome trebale imati sličan udio IKT-a. Kod udjela izvoza IKT proizvoda također postoji razlika, naime Europska unija je smanjivala udio proizvodnje a Hrvatska povećavala. Ovaj nalaz bi djelomično odgovarao sad već davnom istraživanju Škuflić i Vlahinić-Dizdarević iz 2003, gdje su autori uvidjeli da se udio IKT izvoza Hrvatske ne poklapa s ostalim tranzicijskim zemljama. Prije početka prikupljanja empirijskih podataka za ovaj rad pretpostavilo se da bi udio IKT izvoza Hrvatske trebao biti sličan kao u ostalim zemljama Europske unije, posebice s posttranzicijskim; moguće objašnjenje pronađene razlike proizlazi iz relativno kasnijeg ulaska Hrvatske u Europsku uniju te time da nije prošlo dovoljno dugo razdoblje za ujednačenje kretanja, djelomice i to jer se očekivalo da će podaci biti dostupni za još neka novija razdoblja, a ne samo do 2017. godine.

U skladu s očekivanjima godišnje promjene u kretanjima IKT izvoza usluga Hrvatske prate trend Europske unije izuzev dvije posljednje godine. Međutim, suprotno očekivanjima 
godišnje promjene u kretanjima IKT izvoza proizvoda ne prate trend Europske unije. Tumačenje sličnosti i razlika svodi se na to da Hrvatska povećava IKT proizvodnju i usluge, a Europska unija smanjuje proizvodnju usmjerujući resurse u relativno konkurentniji sektor usluga, ali se i ne smije izostaviti činjenica da je Europska unija u 2000. godini imala preko $10 \%$ IKT-a u ukupnom robnom izvozu, a Hrvatska samo $2 \%$. Time se očekuje da bi se udjeli IKT proizvoda u robnom izvozu Hrvatske i EU-a u daljnjem razdoblju trebali ujednačiti (s obzirom na trenutne tendencije rasta u Hrvatskoj i pada u EU-u) te ubuduce kretati zajedničkim stopama jer je sad Hrvatska dio EU-a, a time i zajedničkih tržišnih politika.

Nadalje hrvatski IKT sektor usluga povećava svoju konkurentnost, što je potvrđeno rastom pokazatelja pokrivenosti uvoza, pri čemu je uvoz pokriven gotovo dva puta izvozom u 2019. godini, i to zbog rasta izvoza, a ne pada uvoza. S obzirom na postavljena očekivanja o minimalnoj pokrivenosti IKT uvoza izvozom, može se reći da su ova očekivanja nadmašena u pozitivnom smislu, što ide u prilog tezi o konkurentnosti IKT sektora Hrvatske. S druge strane, uvoz IKT sektora proizvoda pokriven je izvozom samo $30 \%$.

Komparativna prednost hrvatskog IKT sektora proizvoda i usluga prikazala se pomoću indeksa izražene komparativne prednosti (RCA indeks). U skladu s navođenjem nekih autora o nedostacima RCA indeksa (Pascucci, 2018) dodatno je izračunata njegova simetrična vrijednost (RSCA indeks). Rezultati oba indeksa potvrdili su konkurentnost odnosno nekonkurentnost IKT sektora u određenoj godini. Relevantnost RCA indeksa potvrđena je ispunjenim Hillmanovim uvjetom.

Kada se gleda promjena izražene komparativne prednosti, rezultati su pokazali da ju je Hrvatska u IKT sektoru usluga izgubila u odnosu na 2005.godinu. Komparativna prednost veća je kod sektora usluga nego kod proizvoda, ali njihove vrijednosti stagniraju i nisu na zadovoljavajućim razinama, što ne ide u prilog tezi o konkurentnosti IKT sektora Hrvatske.

U budućim istraživanjima trebalo bi se više pažnje posvetiti utjecaju krize uzrokovane koronavirusom na konkurentnost IKT sektora Hrvatske, ali za to će biti potrebno pričekati objavu novih podataka. $\mathrm{U}$ ovim vrlo dinamičnim i neizvjesnim vremenima pokazale su se slabosti različitih analiza o predviđanju budućih kretanja, jer tko je mogao predvidjeti ovakvu situaciju godinu dana prije samo na temelju povijesnih podataka. Za dobivanje svježih podataka mogla bi se provesti anketa o stanju poslovanja za vrijeme ove krize među samim proizvođačima i pružateljima IKT usluga.

\section{ZAKLJUČAK}

Sektor IKT-a (informacijska i komunikacijska tehnologija) važan je doprinos rastu gotovo svakog gospodarstva u Europi. Njegov doprinos rastu može biti izravan i neizravan. Neizravan doprinos gospodarskom rastu očituje se kroz usvajanje novih tehnologija u drugim sektorima, pri čemu oni postaju produktivniji, a time i konkurentniji. Također, važna je i podrška koju IKT pruža nacionalnom gospodarstvu kroz digitalizaciju brojnih procesa, što se pokazalo važno posebice sad za vrijeme krize uzrokovane koronavirusom. Izravan utjecaj IKT sektora prikazuje se kroz njegov doprinos izvozu zemlje, bruto domaćem proizvodu, zapošljavanju i otvaranju novih poduzeća. 
S obzirom na to da se većina istraživanja bazirala na doprinosu IKT-a gospodarstvu kroz porast produktivnosti, njegovom uporabom i neizravno mjere njegov utjecaj u drugim sektorima, pri čemu je tek manji dio njih razmotrio izravan doprinos IKT-a kao sektora. S obzirom na to da dosadašnja istraživanja u Hrvatskoj nisu obuhvatila ovaj skup pokazatelja niti odredila komparativnu prednost IKT sektora, ovaj rad popunio je taj nedostatak.

Kako bi se ispunio glavni cilj ovog rada, tj. analizirati konkurentnost hrvatskog IKT sektora, upotrebljeni su podaci iz različitih baza podataka. Prikazani podaci ukazuju na veliku i rastuću važnost IKT sektora u Hrvatskoj. U IKT sektoru dominiraju usluge s tendencijom rasta, dok proizvodi čine manji dio, iako još uvijek ispod prosjeka Europske unije. Slijedom prikazanih podataka o kretanju odnosa IKT proizvoda i usluga moglo bi se zaključiti da je uzrok rastu usluga proces deindustrijalizacije i selidba proizvodnje u zemlje s jeftinijom radnom snagom, jer kako je vidljivo mnoge zemlje Europe smanjuju IKT proizvodnju. Na kraju, iako možda Hrvatska u nekim segmentima zaostaje za Europskom unijom, u IKT sektoru konkurentnost hrvatskog IKT sektora usluga je vrlo dobra, što je pokazano pokazateljem pokrivenosti uvoza IKT usluga izvozom. U daljnjem razdoblju očekuje se još veće približavanje Hrvatske europskim trendovima zbog korištenja zajedničkih politika koje teže ujednačenom razvoju svih dijelova Unije. Međutim, na području međunarodne konkurentnosti pomalo zabrinjava relativno nizak indeks izražene komparativne prednosti IKT sektora. Iako je u skladu s dominantnijom pozicijom usluga njihov pokazatelj povoljniji nego u slučaju proizvoda ni jedan ni drugi nemaju zadovoljavajuću vrijednost, a tendencije kretanja ukazuju da stagniraju, što ne ulijeva nadu u poboljšanje. Ispunjenost Hillmanova uvjeta u svim godinama promatranog razdoblja za IKT sektor proizvoda i usluga ukazuje da se RCA indeks može koristiti kao pokazatelj razine komparativne prednosti IKT sektora Hrvatske.

Nije potrebno isticati značaj problema uzrokovanog koronavirusom na svjetsko gospodarstvo, IKT tu igra i igrat će još veću ulogu. Naime, u mnogim djelatnostima moguće je organizirati rad od kuće, webinare, e-trgovine, e-tržnice, e-učenje i sl. Bez IKT proizvoda i usluga to ne bi bilo moguće, stoga se u narednom razdoblju očekuje rastući značaj IKT-a u strukturi izvoza kako robe tako i usluga, ali i sve veći utjecaj doprinosu BDP-u. Zemlje koje smanjuju IKT proizvodnju možda će u budućnosti ipak više podrške pružiti tom sektoru jer ovisnost isključivo o uvozu, u nekim trenucima ključnih komponenti ne bi bila dobra.

Neka od ograničenja koja su se pojavila kod ove analize svakako se odnose na razvrstavanje pojedinih djelatnosti u sektore te definiranje obuhvata IKT sektora. Od ostalih ograničenja može se istaknuti i problematika podjele samog IKT sektora na proizvode i usluge; korištene baze podataka pokušale su na donekle objektivan način razvrstati IKT proizvode i usluge, međutim u suvremenim uvjetima jasna granica ne postoji jer se proizvodi uglavnom nadograđuju u sustave tako rijetko kad postoji samo proizvod ili samo usluga.

\section{LITERATURA}

[1] Anca, H. (2012). Literature review of the evolution of competitiveness concept. The annals of the university of oradea. Economic sciences, 1(1), 41-46.

[2] Balassa, B. (1965). Trade liberalization and revealed comparative advantage. Manchester School of Economics and Social Studies, 33(2), 99-124. 
[3] Branković, A. (2015.) Izvozna konkurentnost privrede Republike Srbije pod uticajem tranzicionih promena. u Stošić, I ur. Strukturne promene u Srbiji dosadašnji rezultati i perspektive : tematski zbornik, Institut ekonomskih nauka, Beograd 48-65.

[4] Cioaca, S. et al. (2020). Assessing the Impactof ICT Sector on Sustainable Development in the European Union: An Empirical Analysis Using Panel Dana. Sustainability, 12(2)

[5] Ciriani, S \& Perin, P. (2017). Trends in Global ICT Trade. Communications and strategies, 107, 17-47.

[6] Cortes, E. A. \& Navarro, J. A. (2011). Do ICT Influence Economic Growth and Human Development in European Union Countries? International Advances in Economic Research, Vol. 17(1), 28-44.

[7] Crafts, N. \& Mills, T. C. (2020). Is The Uk Productivity Slow down Unprecedented? National Institute Economic Review, 251, 47-53.

[8] Čorejova, T. \& Madudova, E. (2019). Trends of scale-up effects of ICT sector. Transportation Research Procedia, 40, 1002-1009.

[9] Dahl, C. M. et al. (2011). ICT and productivity grow thin the 1990s: panel data evidence on Europe. Empirical Economics volume, 40, 141-164.

[10] Delina, R. (2004). Aplikovaná ekonometrika pri hodnotení efektívnosti elektronického obstarávania. Ekonomie a Management, 7(2), 35-46.

[11] Department of Economic and Social Affairs (2008). International standard industrial classification of all economic activities. https:/unstats.un.org/unsd/publication/seriesM/seriesm_4rev4e.pdf (pristup: 17.06. 2020.)

[12] Doucker, P. (2010). Human resource in ICT - ICT effects on GDP. IDIMT-2010 Information Technology - Human Values, Innovation and Economy, 97-105.

[13] Državni zavod za statistiku (2019). Priopćenje, Primjena informacijskih i komunikacijskih tehnologija (IKT) u poduzećima u 2019. Prvi rezultati, Broj 2.3.1

[14] Državni zavod za statistiku (2020). Prva procjena tromjesečnog bruto domaćeg proizvoda za prvo tromjesečje 2020. Broj 12.1.1/1.

[15] Duc, D. T. \& Linh, D. H. (2020). Analysing ICT Economic Impact inVietnam. Research in World Economy, (11(5)

[16] Ebijuwa, A. A. (2005). Information and Communication Technology in university libraries: The Nigeria experience. Journal of Library and Information Science, 7(1-2) 23-30.

[17] Europska komisija (2020). EU Budget for the future. https://ec.europa.eu/digital-single-market/en/news/digital-europe-programme-proposed-eu92-billion-funding-2021-2027 (pristup: 16. 06. 2020.)

[18] Europska unija (2002). European Competitiveness Report 2002 https://ec.europa.eu/ growth/content/european-competitiveness-report-2002-0_en (pristup: 16. 06. 2020.)

[19] Eurostat (2020.) Udio IKT sektora u BDP-u https://appsso.eurostat.ec.europa.eu/nui/ show.do?dataset=isoc_bde15ag\&lang=en (pristup: 20. 06. 2020.)

[20] Fratto, C \& Giannone, E. (2020). Market Access and Development of the ICT Sector in the West Bank. Policy Research Working Papers. https://elibrary.worldbank.org/ doi/abs/10.1596/1813-9450-9426 (pristup 28. 12. 2020.) 
[21] Henten, A. \& Tadayoni, R. (2015). The dominance of the IT industry in a converging ICT ecosystem. https://vbn.aau.dk/en/publications/it-industriens-dominans-i-et-konvergerende-ikt- $\varnothing \mathrm{k} \varnothing \mathrm{s} y s t e m$ (pristup: 19. 06. 2020.)

[22] Hillman, A. (1980). Observations on the relation between "revealed comparative advantage" and comparative advantage as indicated by pretrade relative prices. $R e$ view of World Economics 116(2), 315-321.

[23] International Trade Centre (2020. a) Popis zemalja uvoznica za izvezene usluge hrvatskog sektora usluga: 9 - Telekomunikacijske, računalne i informacijske usluge https:// www.trademap.org/Country_SelServiceCountry_TS.aspx?nvpm=1\%7c191\%7c\%7c\%7c\%7c\%7c\%7cS09\%7c1\%7c3\%7c1\%7c2\%7c2\%7c1\%7c2\%7c1\%7c1\%7c1 (pristup: 22. 10. 2020.)

[24] International Trade Centre (2020. b) Popis zemalja uvoznica za izvezene usluge hrvatskog sektora usluga: - Sve usluge https://www.trademap.org/tradestat/Country_SelServiceCountry_TS.aspx?nvpm $=1 \% 7 \mathrm{c} 191 \% 7 \mathrm{c} \% 7 \mathrm{c} \% 7 \mathrm{c} \% 7 \mathrm{c} \% 7 \mathrm{c} \% 7 \mathrm{cS} 00 \% 7 \mathrm{c} 1 \% 7 \mathrm{c} 3 \%$ 7c1\%7c2\%7c2\%7c1\%7c2\%7c1\%7c1\%7c1 (pristup: 22. 10. 2020.)

[25] International Trade Centre (2020. c) Popis zemalja opskrbnog tržišta usluga za Hrvatsku: 9 - Telekomunikacijske, računalne i informacijske uslugehttps://www.trademap. org/Country_SelServiceCountry_TS.aspx?nvpm=1\%7c191\%7c\%7c\%7c\%7c\%7c\%7cS09\%7c1\%7c3\%7c1\%7c1\%7c2\%7c1\%7c2\%7c1\%7c1\%7c1 (pristup: 22. 10. 2020.)

[26] International Trade Centre (2020. d) Popis zemalja izvoznica usluga: Sve usluge https:// www.trademap.org/Country_SelService_TS.aspx?nvpm $=1 \% 7 \mathrm{c} \% 7 \mathrm{c} \% 7 \mathrm{c} \% 7 \mathrm{c} \% 7 \mathrm{c} \% 7 \mathrm{c} \%$ 7cS00\%7c1\%7c3\%7c1\%7c2\%7c2\%7c1\%7c2\%7c1\%7c1\%7c1 (pristup: 29. 12. 2020.)

[27] International Trade Centre (2020. e) Popis zemalja izvoznica usluga: - Telekomunikacijske, računalne i informacijske usluge https://www.trademap.org/Country_SelService_TS.aspx?nvpm $=1 \% 7 \mathrm{c} \% 7 \mathrm{c} \% 7 \mathrm{c} \% 7 \mathrm{c} \% 7 \mathrm{c} \% 7 \mathrm{c} \% 7 \mathrm{cS} 09 \% 7 \mathrm{c} 1 \% 7 \mathrm{c} 3 \% 7 \mathrm{c} 1 \% 7 \mathrm{c} 2 \% 7 \mathrm{c} 2 \%$ 7c1\%7c2\%7c1\%7c1\%7c1 (pristup: 29. 12. 2020.)

[28] Jorgenson, D. W. \& Stiroh, K. J. (2000). Raising the speed limit: US economic growth in the information age, OECD Economics Department Working Papers, 261

[29] Keček, D. et al. (2016). Analysis of multiplier effects of ICT sectors - a Croatian case. Croatian Operational Research Review, 7(1) 129-145.

[30] Keček, D. et al. (2019). Effects of final expenditures on ICT goods and services on the croatian domestic output andimports - the input-output approach. Economic Research-Ekonomska Istraživanja, 32(1), 531-554.

[31] Kiraly, O. et al. (2020). Preventing problematic internet use during the COVID-19 pandemic: Consensus guidance. Comprehensive Psychiatry, https://doi.org/10.1016/j. comppsych.2020.152180 (pristup: 18. 06. 2020.)

[32] Kleibrink, A et al. (2018). The Potential of ICT in Serbia: An Emerging Industry in the European Context. Publications Office of the European Union, https://core.ac.uk/ download/pdf/162257374.pdf (pristup 28. 12. 2020.)

[33] Kovačević, Z. \& Vuković, K. (2006). Performanse poduzeća u hrvatskom sektoru informacijsko-komunikacijske tehnologije (ICT). Poslovna izvrsnost, 1(1), 98-112.

[34] Krugman, P. (1994). Competitiveness: A Dangerous Obsession. Foreign Affairs, 73(2), 28-44. 
[35] Mallick, M. F. \& Chaudhary, A. (2016). Performance And Export Competitiveness Of ICT Industry-A Comparative Analysis Of India And China. International Journal of Innovative Research \& Growth, 4(1), 19-28.

[36] Martin, R. L. (2004). Study on the Factors of Regional Competitiveness, https:// ec.europa.eu/regional_policy/sources/docgener/studies/pdf/3cr/competitiveness.pdf (pristup: 19.06. 2020.)

[37] Martinović, M. et al. (2014). Use Of Ict Sector In Order To Improve And Develop Competitiveness Of Eastern Croatian Economy. Zbornik radova: 3th International scientific symposium "Economy of Eastern Croatia - vision and development", 84-96.

[38] Mollins, J. \& St-Amant, P. (2019). The productivity slowdown in Canada: An ICT phenomenon? Bank of Canada Staff Working Paper 2019-2

[39] OECD (2011) OECD Guide to Measuring the Information Society 2011. https://www. oecd.org/sti/ieconomy/oecdguidetomeasuringtheinformationsociety2011.htm (pristup: 17. 06. 2020.)

[40] OECD, (2019). Measuringthe Digital Transformation. https://www.oecd-ilibrary.org/ docserver $/ 9789264311992$-en.pdf?expires $=1592561057 \& \mathrm{id}=\mathrm{id} \&$ accname $=$ guest\&checksum=4C8533B4AB4C56FD9F1DAF95426E3168 (pristup:19. 06. 2020.)

[41] Ojo, M. (2020). Digitalization and the Modern Economy in the COVID-19 Age: Speedor Timing, Whic his More Important? Economic Review, https://papers.ssrn.com/ sol3/papers.cfm?abstract_id=3613234 (pristup:17. 06. 2020.)

[42] Pascucci, F. (2018.) The export competitiveness of Italian cofferoasting industry. British Food Journal. 120(7), 1529-1546.

[43] Porter, M. E., (1998). The Competitive Advantage of Nations, Free Press, New York

[44] Psychoyios, D. i Dotsis, G. (2018). The competitiveness of the European ICT Industry. Review of Economic Analysis, 10, 97-119.

[45] Pužova, M. \& Marešova, P. (2014). Czech Republics Competitiveness in ICT Market. Procedia - Social and Behavioral Sciences 109(8), 880 - 885.

[46] Rašić-Bakarić, I. \& Vizek, M. (2010). Analiza konkurentnosti i strukturnih obilježja prerađivačke industrije Republike Hrvatske. Ekonomski pregled, 61(5-6), str. 241-270.

[47] Schwab, K. (2019). The Global Competitiveness Report 2019, World Economic Forum

[48] Shkalenko, A. V. \& Fadeeva, E. A. (2020). Analysis of the Impact of Digitalization on the Development of Foreign Economic Activity During COVID-19 Pandemic. https:// www.atlantis-press.com/proceedings/mtde-20/125939866 (pristup: 17. 06. 2020.)

[49] Sivakumaren, K. S. et al (2011). ICT Facilitiesin University Libraries: A Study. Library Philosophy and Practice, https://digitalcommons.unl.edu/libphilprac/628/?utm_source $=$ digitalcommons.unl.edu\%2Flibphilprac\%2F628\&utm_medium=PDF\&utm_ campaign=PDFCoverPages (pristup: 19.06. 2020.)

[50] Stojanov, D. et al. (2011). Izvozna konkurentnost Primorsko-goranske županije. Ekonomski vjesnik: Review of Contemporary Entrepreneurship, Business, and Economic Issues 24(1), 33-46. 
[51] Startiene, G. \& Remeikiene, R. (2013.) Evaluation of Revealed Comparative Advantage of Lithuanian Industry in Global Markets. Procedia - Social and Behavioral Sciences 110(24), 428-438.

[52] Škuflić, L. \& Vlahinić-Dizdarević, N. (2003). Koncept nove ekonomije i značaj informacijsko-komunikacijske tehnologije u Republici Hrvatskoj. Ekonomski pregled, 54(5-6), 460-479.

[53] Škuflić, L. et al. (2011). Uloga fiskalne politike u jačanju konkurentnosti hrvatskog gospodarstva. Tranzicija, 13(28), 1-17.

[54] Tijanić. L. (2010). Regionalna (ne)konkurentnost u republici Hrvatskoj. Ekonomski pregled, 61(7-8), 419-454.

[55] ToAnyakoha, M.W. (2005). Information and Communication Technology (ICT) in library services. Coal City Libraries, 2(1-2), 2-12.

[56] United Nations Conference on Trade and Development (2020. a) Izvoz IKT proizvoda Hrvatska/svijet. https://unctadstat.unctad.org/wds/TableViewer/tableView. aspx?ReportId=15850 (pristup: 29. 12. 2020.)

[57] United Nations Conference on Trade and Development (2020. b) Izvoz i uvoz roba i usluga, Hrvatska/svijet. https://unctadstat.unctad.org/wds/TableViewer/tableView.aspx?ReportId=89795 (pristup: 29. 12. 2020.)

[58] United Nations Conference on Trade and Development (2020 . c) Uvoz IKT proizvoda, Hrvatska https://unctadstat.unctad.org/wds/TableViewer/tableView.aspx (pristup: 30. 12. 2020.)

[59] Vedriš, M. (2005). Konkurentnost nacionalne ekonomije-osnova izvoznih performansi zemlje. Ekonomija Economics, 12(1) 37-55.

[60] World Bank (2020. a) Izvoz IKT usluga (kao postotak ukupnog izvoza usluga) https:// data.worldbank.org/indicator/BX.GSR.CCIS.ZS (pristup: 20. 06. 2020.)

[61] World Bank (2020. b) Izvoz IKT proizvoda (kao postotak ukupnog robnog izvoza) https://data.worldbank.org/indicator/TX.VAL.ICTG.ZS.UN (pristup: 22. 10. 2020.) 